\title{
Tax Policy and Retirement Income: Are Pension Plan Anti-Discrimination Provisions Desirable?
}

Joseph Bankman†

Federal tax law strongly encourages retirement saving through employee pension plans. Employers may immediately deduct the amounts they contribute to such plans. Employees, on the other hand, are not taxed on either the contributions or the interest earned on the contributions until they retire, when their tax rates are often lower. This favorable tax treatment is conditioned, however, upon compliance with certain "anti-discrimination" rules. A plan will meet the requirements of those rules only if rank-and-file employees receive pension benefits at a rate comparable to that offered to highly compensated employees.

This article examines the social utility of the pension plan anti-discrimination provisions. Part I discusses tax and other characteristics of private pensions, and provides an overview of the pension plan anti-discrimination provisions.

Part II examines the history and prior scholarly analysis of the anti-discrimination requirements. The anti-discrimination provisions were enacted without significant discussion; only a handful of articles have explored the rationale for these provisions.

Parts III through VI explore a number of possible justifications for the requirements. Part III uses a partial equilibrium model to examine the argument that the anti-discrimination provisions increase employee welfare. This model suggests that the antidiscrimination provisions generally will reduce both the amount of cash compensation and the perceived value of the compensation

$\dagger$ Associate Professor, The Law Center, The University of Southern California. A.B. 1977, University of California at Berkeley; J.D. 1980, Yale University. The author wishes to thank David Anderson, Patricia Cain, Richard Craswell, Ron Garet, Thomas Griffith, David I. Halperin, Catherine Hantzis, William Klein, Norman Lane, Martin Levine, Margaret Radin, Adrienne Salkin, Mathew Spitzer, John Stick, and Jeff Strnad for their helpful comments.

The author is honored to appear in an issue dedicated to Walter J. Blum. For many years, Professor Blum has been one of the nation's most eloquent, astute, and respected tax scholars. His writings on many important issues-ranging from progressivity to capital gains to corporate taxation-have significantly advanced our understanding of tax policy. 
package to rank-and-file employees. The anti-discrimination provisions will also generally reduce revenue to the public fisc and increase labor costs.

The conclusions drawn from the partial equilibrium model depend critically on the assumption that rank-and-file employees make market decisions consistent with their long-term interests. Part IV conditionally rejects this assumption, and reexamines the impact of the anti-discrimination provisions on employee welfare. Here, the increased pension benefits and reduced cash compensation produced by the anti-discrimination provisions might be seen as a means by which to force rank-and-file employees to save for retirement. Forced saving may increase welfare and constitute a desirable form of state paternalism; forced saving may also reduce support costs otherwise borne by the state. However, the anti-discrimination requirements appear to be an arbitrary and ineffective means by which to effect such retirement savings.

Part $\mathrm{V}$ examines and rejects the argument that the anti-discrimination provisions are supported by considered ideals of equality.

Part VI examines the argument that the anti-discrimination requirements are justified as a means by which to reduce the pension benefits of highly compensated employees. The reduction of tax-favored benefits would be consistent with certain theories of the tax structure and might also be supported on revenue-related and distributional grounds. However, the anti-discrimination provisions seem an unprincipled and unreliable way to bring about such a reduction.

Part VII summarizes the case for and against the anti-discrimination provisions and makes a number of specific policy recommendations. Based on present knowledge, the anti-discrimination provisions should be eliminated. Limitations on tax benefits to highly compensated employees should be enacted directly, through reductions in the maximum dollar amounts eligible for favorable tax treatment. An increase in retirement saving, if desired, should also be effected directly, through the establishment of universal employer or government-managed private pensions. Alternatively, retirement income may be augmented through an increase in social security or tax-transfer payments. 


\section{INTRODUCTION}

\section{A. Definition and Function of Private Pensions}

There are many forms of private pensions. ${ }^{1}$ In general, however, a private pension may be thought of as an arrangement under which employers or employees contribute to tax-exempt trusts. ${ }^{2}$ Employers serve as trust fiduciaries; ${ }^{3}$ employees are trust beneficiaries. Upon retirement, employees receive benefits, most often in the form of lifetime monthly payments or annuities. ${ }^{4}$ Less frequently, pension plans are funded through direct purchase of annuities from life insurance companies. Most pensions fall into one of two categories. Defined benefit plans guarantee employees a predetermined amount upon retirement. ${ }^{5}$ Defined contribution plans provide employees with a specified annual contribution; the amount available upon retirement depends on the investment gains or losses of the accumulated contributions. ${ }^{6}$

Private pensions may serve a number of useful functions. Employees may prefer the professional plan management to the alternative of self-directed retirement savings. Many pensions offer generous early retirement benefits that may serve as a form of insurance against poor health or as a way to ensure a young and effi-

' See David S. Dunkle, Guide to Pension and Profit Sharing Plans, § 1.03 (1985 \& Supp. 1987); Boris I. Bittker, 2 Federal Taxation of Income, Estates and Gifts 1 61.1.2 (1981 \& Cum.Supp. 1987).

${ }^{2}$ Employee contributions are much less common than employer contributions, probably because of disparate tax treatment. Employees are fully taxed on income which they elect to contribute to qualified pension plans. In contrast, employer contributions are not taxed as income to the employee until the amounts are withdrawn. This deferral creates a considerable tax advantage for employer contributions. See Dunkle, Guide to Pension Plans at $\$ 1.03$ (cited in note 1).

${ }^{3}$ Employer-appointed advisors, such as accountants, lawyers, or financial institutions, generally serve as trustees; representatives from labor also may serve as trustees.

- In some cases, employees are given, or may elect to receive, their pension benefits in a lump sum upon retirement. If a retirement annuity is offered, however, benefits must run for the lives of both the employee and the employee's spouse, unless this requirement is properly waived by the employee. 26 U.S.C. $\S \S 401$ (a)11, 417 (a) (1988). All subsequent references to the United States Code are to Title 26 unless otherwise indicated.

s The amount of the benefit generally will be determined under a formula which takes into account age, years of service, and salary. Thus, a typical defined benefit plan may provide a retiree with monthly benefits equal to one-hundredth of her average monthly salary multiplied by her years of service. See generally the authorities cited in note 1 .

- Defined contribution plans are described in Dunkle, Guide to Pension Plans at $\$ 1.05$ (cited in note 1). The relative advantages and disadvantages of defined benefit and defined contribution plans from a worker security perspective are discussed in Michael J. Graetz, The Troubled Marriage of Retirement Security and Tax Policies, 135 U.Pa.L.Rev. 851 (1987). 
cient workforce. ${ }^{7}$ However, it is generally assumed that the growth and structure of private pension plans is in part a product of federal tax law. ${ }^{8}$ Under the current scheme, employers may deduct contribution to plans in the year in which contributions are made. ${ }^{9}$ Employees, on the other hand, generally are not taxed on contributions or upon the interest earned on contributions until the accumulated funds are withdrawn upon retirement. ${ }^{10}$ This treatment differs from that afforded to cash wages and salaries, which are immediately taxable as income.

The tax benefit of the deferral offered by such "pension savings" provisions is considerable. An employee who receives an annual pension contribution of $\$ 2,000$ placed in a $10 \%$ interest-bearing account will accumulate pension benefits of approximately $\$ 885,000$ at the end of 41 years. ${ }^{11}$ If that sum is withdrawn and subject to a $28 \%$ federal income tax, the amount available for consumption will be approximately $\$ 640,000 .^{12}$ By contrast, if an employee in a $28 \%$ federal tax bracket invests the after-tax proceeds

7 These and other functions of the private pension system are discussed at length in David A. Wise, ed., Pensions, Labor, and Individual Choice (1985), and Zvi Bodie and John B. Shoven, eds., Financial Aspects of the United States Pension System (1983).

8 See Richard A. Ippolito, Pensions and Economics: Towards an Efficient Retirement Policy, in Jack L. VanDerhei, ed., Search for a National Retirement Income Policy at 33, 67 (1987) ("It is inconceivable that the size of the current private system is not largely attributable to the special pension tax provisions in the U.S. tax code."); Alicia H. Munnell, The Economics of Private Pensions 30-61 (1982). A less conclusory discussion of the impact of the tax system on pension growth is found in Edward P. Lazear, Pensions as Severance Pay, in Bodie and Shoven, eds., Financial Aspects at 57-58 (cited in note 7).

A number of studies have examined the relationship between tax rates and fringe benefits generally. The results and methodology of these studies vary, but almost all studies find the amount of fringe benefits to be positively correlated with the tax rate. See Robert $W$. Turner, Are Taxes Responsible for the Growth in Fringe Benefits?, 40 Natl. Tax J. 205 (1987); Frank A. Sloan and Killard W. Adamache, Taxation and the Growth of Nonwage Compensation, 14 Pub.Fin.Q. 115 (1986).

- $\$ \$ 404,162$.

$10 \S \S 402-03$.

1 The formula for computing the future sum of period payments may be expressed as:

$$
R *\left[\frac{(1+i)^{n-1}-1}{i}\right]
$$

where $R$ is the amount of the periodic payment, $i$ is the interest rate and $n$ is the number of periods. In the present example, the formula produced a future sum of $\$ 885,185$. As of June 30,1987 , the interest rate offered on deferred retirement annuities by Mutual Benefit Life was $9.25 \%$, and as of the twelve month ending April 30, 1987, the annualized net yield from the Fidelity High Income Fund was $11 \%$.

${ }_{12}$ At a $28 \%$ rate, the tax on $\$ 885,000$ will be approximately $\$ 245,000$, leaving $\$ 640,000$ for consumption. 
of $\$ 2,000$ into a currently taxed $10 \%$ interest-bearing account, the amount available for consumption at the end of 41 years will come to only about $\$ 300,000 .^{13}$ The tax benefits of pension savings normally are increased by accompanying state tax provisions, ${ }^{14}$ by the absence of social security and hospital insurance tax on contributions and benefits, ${ }^{15}$ by the lower overall tax rate often faced upon retirement, ${ }^{16}$ and by special income averaging provisions which may further reduce retirement-age tax rates. ${ }^{17}$ If, for example, the individual described above faced a working-age combined state and federal tax rate of $33 \%$ and a retirement-age tax rate of $15 \%$, the use of a pension plan would increase the amount available for consumption from approximately $\$ 250,000$ to $\$ 750,000.1^{18}$

Fueled by tax and other advantages, pension plans have become an increasingly significant source of retirement savings and income. Pension plans have increased in number forty-fold in the past forty years, ${ }^{19}$ and now cover a majority of all workers who

1s The $28 \%$ tax rate would reduce annual contributions by $\$ 560(.28 * \$ 2,000)$ to $\$ 1440$ and the annual interest rate by 2.8 points $(.28 * 10 \%)$ to $7.2 \%$. The calculation of the amount available at the end of the period may be made using these revised figures and the formula described in note 11.

14 Nearly all state income taxes are modelled after the federal income tax and contain similar or identical pension plan provisions.

${ }^{15}$ In 1988, employees pay an Old Age Survivors and Disability Insurance (social security) tax of $6.06 \%$ on the first $\$ 45,000$ of wages; employers pay a like amount per employee. $\S \S 3101$ (a), 3111(a), 3121(a); 42 U.S.C. § 430; Department of Health and Human Services, 1988 Cost-of-Living Increase and Other Determinations, 52 Fed.Reg. 41672 (1987). Employees and employers also pay a Hospital Insurance (medicare) tax of $1.45 \%$ on the first $\$ 45,000$ of wages. $\S \S 3101(\mathrm{~b}), 3111(\mathrm{~b}), 3121(\mathrm{a})$. Pension contributions and benefits, however, are exempt from social security and medicare taxes. $\$ 3121(a)(5)$. In some cases, the advantages of reduced social security tax may be offset by reduced social security payments. See Robert J. Myers, Social Security 21-166 (1975).

${ }^{18}$ Retirees face lower marginal tax rates because, on the average, they have less taxable income. However, the advantage to postponing the recognition of income until after retirement was reduced by the Tax Reform Act of 1986, which reduced the maximum marginal tax rate from $50 \%$ to $33 \%$ for taxable years beginning in 1988 .

${ }_{17}$ Under $\$ 402(e)$, certain lump-sum pension distributions are taxed at the rate that would apply if such distributions were received in equal increments during five years in which the recipient had no other income. This income-averaging virtually ensures that a large percentage of the distribution will be taxed at a low marginal rate.

${ }_{18}$ The combination of the maximum federal rate of $28 \%$, plus the federal surtax of $5 \%$ levied on certain income ranges, plus the social security tax of $7.51 \%$, plus state taxes may result in actual marginal tax rates in excess of $45 \%$.

19 The number of private pensions increased from approximately 12,000 in 1949-50 to about 500,000 in 1983. Congressional Quarterly, Social Security and Retirement: Private Goals, Public Policy 111, 115 (1983). Contributions, plan assets and number of employees covered exhibit a similar increase. See Munnell, Economics of Private Pensions at 11 (Table 2-1)(cited in note 8 ). 
have more than a year of service with their present employer. ${ }^{20}$ Pension plan contributions account for over $5 \%$ of private sector wages, ${ }^{21}$ and, in most income classes, pension plan distributions account for over one-fourth of all income for persons over age $65 . .^{22}$

\section{B. Pension Plan Anti-Discrimination Provisions}

The favorable tax treatment of pension plans is conditioned upon compliance with two somewhat distinct sets of rules and regulations. The first set of rules is aimed at preventing employer fraud or misrepresentation. The trust instrument must make it impossible for any part of the corpus or income to be used for impermissible purposes, ${ }^{23}$ pensions must be adequately funded to meet future liabilities, ${ }^{24}$ employers are required to disclose plan eligibility, vesting and benefit provisions to employees, ${ }^{25}$ and, where information costs make disclosure impractical, plan provisions must meet standards based on employee expectations. These consumer protection-oriented rules are supplemented by detailed tax and labor statutes which impose excise taxes and other penalties for breach of fiduciary duty or engagement in certain prohibited transactions. ${ }^{28}$

The second set of rules is designed to prevent discrimination in favor of highly compensated employees, a group which is statutorily defined to include 5\% owners, employees who receive annual compensation in excess of $\$ 75,000$, officers who receive annual compensation in excess of $\$ 45,000$, and employees who receive annual compensation in excess of $\$ 50,000$ and whose compensation places them in the upper $20 \%$ of the organization's employees. ${ }^{27}$

20 President's Commission on Pension Policy, Coming of Age: Toward a National Retirement Income Policy 27 (1981) (58\% of all workers within a year of service with current employer are covered by a pension plan; pension coverage increases as age, income and employer sizes increases). See also Munnell, Economics of Private Pensions at 54 (cited in note 8).

${ }^{21}$ Munnell, Economics of Private Pensions at 52 (Table 3-4)(cited in note 8) (pension and profit-sharing contributions accounted for approximately $5.8 \%$ of 1980 private sector wages and salaries).

22 President's Commission, Coming of Age at 14 (cited in note 20).

${ }^{23} \S 401(a)(2)$.

$24 \S 412$.

2526 C.F.R. § 1.401-1(a)(2) (1987).

${ }^{26}$ Section 503(b) denies tax-exempt status to pension trusts whose assets or income have been involved in certain prohibited transactions. The Employee Retirement Income Security Act of 1974 ("ERISA") directs the Secretary of Labor to administer an excise tax on prohibited transactions. 26 U.S.C. $\$ 4975(c)$. ERISA also establishes liability for breach of fiduciary duties. 29 U.S.C. $\$ 1109$.

${ }^{27} \S 414(q)(1)$. The definition of "highly compensated employee" set forth in § 414(q)(1) 
In general, the anti-discrimination provisions require the ratio of pension contributions or benefits to salary for highly compensated employees to be no greater than the ratio of pension contributions or benefits to salary for non-highly compensated "rankand-file" employees. ${ }^{28}$ Thus, a defined contribution plan which provides highly compensated employees with annual contributions equal to $5 \%$ of compensation must provide rank-and-file employees with annual contributions of at least $5 \%$ of compensation. A defined benefit plan which provides highly compensated employees with annual retirement benefits of $50 \%$ of average annual compensation must provide non-highly compensated employees with annual retirement benefits of at least $50 \%$ of average annual compensation.

The anti-discrimination provisions are mandatory and cannot be waived by the rank-and-file employee. The provisions apply in slightly attenuated form even under so-called "cash or deferred arrangements," in which each employee is allowed to select a desired ratio of pension benefits to salary. A cash or deferred plan will lose its tax qualified status if the ratio selected by highly compensated employees significantly exceeds the ratio selected by rank-and-file employees. ${ }^{2 \theta}$ The anti-discrimination rules do not, however, apply to employees covered by collective bargaining agreements. ${ }^{30}$

The general requirement of strict proportionality is relaxed somewhat by a network of "integration" provisions. Under these provisions, employer social security contributions (or, for a defined benefit plan, social security benefits attributable to employer contributions), are treated as pension plan contributions or benefits. ${ }^{31}$

is modified by other subsections of $\S 414(q)$. These subsections in some cases contract, and in other cases expand, the definition of highly compensated employee. The arbitrariness of the statutory definition is forcefully argued in Nancy J. Altman, Rethinking Retirement Income Policies: Nondiscrimination, Integration, and the Quest for Worker Security, 42 Tax L.Rev. 433, 457-60 (1987). See also Daniel I. Halperin, Tax Policy and Retirement Income: A Rational Model for the 21st Century, in VanDerhei, ed., National Retirement Policy at $159,173-75$ (cited in note 8).

${ }^{28} \S 401(a)(5)$.

${ }^{29} \S 401(\mathrm{k})(3)$. In 1989 and subsequent taxable years, a cash or deferred arrangement will fail the anti-discrimination requirements unless it satisfies one of the following tests: (1) the ratio of pension benefits to salary for high compensated employees is not greater than 1.25 times the ratio for rank-and-file employees; or (2) the ratio of pension benefits to salary for highly compensated employees is not more than 2 percentage points greater than the ratio for rank-and-file employees and is not greater than 2 times the ratio for rank-and-file employees. $\$ 401(\mathrm{k})(3)(\mathrm{A})(\mathrm{ii})$.

30 $\S 401(a)(4), 410(b)(3)(A)$.

${ }^{31} \S 401(1)$. The integration provisions are criticized in Altman, 42 Tax L.Rev. at 478-98 (cited in note 27). Similar criticism is levied by Halperin, Tax Policy and Retirement In- 
Social security contributions are made as a percentage of the "wage base" (currently $\$ 45,000$ per annum); no social security tax is levied on amounts in excess of the wage base. The inclusion of social security contributions in the anti-discrimination calculation enables employers to skew actual pension contributions in favor of highly compensated employees. For example, an employer who makes social security contributions equal to $6 \%$ of the first $\$ 45,000$ of compensation might adopt a tax-qualified pension plan under which employees receive contributions equal to $10 \%$ of the first $\$ 45,000$ of compensation and $16 \%$ of compensation in excess of $\$ 45,000$. In both cases, the sum of social security contributions and pension contributions would amount to $16 \%$ of compensation and therefore would comply with the anti-discrimination requirements.

The integration rules, like many of the anti-discrimination provisions, are subject to a number of arbitrary limits. For example, the ratio of contributions to salary for rank-and-file employees, determined without regard to social security contributions, cannot be less than half the ratio of contributions to salary for highly compensated employees. ${ }^{32} \mathrm{~A}$ similar limit applies to the ratio of benefits to salary received under a defined benefit plan..$^{33}$

Moreover, the relaxation of strict proportionality offered by the integration rules is in some cases more than offset by application of the so-called "top-heavy" provisions. ${ }^{34}$ The top-heavy provisions apply in cases in which, although benefits or contributions are made in proportion to salary, only a small portion of total benefits or contributions accrue to workers on the low end of the pay

come at 173-75 (cited in note 27); Graetz, The Troubled Marriage of Retirement Security and Tax Policies at 888 (cited in note 6); Bruce Wolk, Discrimination Rules for Qualified Retirement Plans: Good Intentions Confront Economic Reality, 70 Va.L.Rev. 419, 449 (1984).

${ }^{32} \S 401$ (1)(2) (effective for taxable years beginning in 1989). The effect of $\S 401$ (1)(2) may be illustrated by the following hypothetical. Assume all rank-and-file employees earn compensation of $\$ 25,000$, all highly compensated employees earn compensation of $\$ 85,000$, and the employer makes mandatory social security contributions equal to $6.0 \%$ of the first $\$ 45,000$ of compensation. The integration rules would generally permit the employer to make pension contributions equal to $6.0 \%$ of compensation in excess of $\$ 45,000$, and no contributions on compensation below that amount; in each case, the sum of social security and pension contributions would be equal to $6.0 \%$ of compensation. Thus, an employer might make pension contributions of $\$ 2,400$ for each highly compensated employee $(6.0 \%$ of the excess of $\$ 85,000$ over the $\$ 45,000$ social security wage base) and zero for each rank-andfile worker. However, such a plan would not qualify under $\S 401(\mathrm{I})(2)$, because the ratio of non-social security (pension) contributions to salary for highly compensated employees would be greater than twice the ratio for rank-and-file workers. The ratio for highly compensated employees would be about $3.0 \%$; the ratio for rank-and-file workers would be $0 \%$.

${ }^{33} \S 401(1)(3)$.

$34 \S 416$. 
scale. This situation may arise if the organization has few low-paid employees.

Somewhat inexplicably, discrimination for the purposes of the top-heavy provisions is measured not with reference to highly compensated employees, but to a more restricted group of "key" employees. ${ }^{35} \mathrm{~A}$ plan will be characterized as top-heavy if more than $60 \%$ of benefits or contributions accrue to key employees. ${ }^{36} \mathrm{~A}$ topheavy plan will retain tax-qualified status only if it meets one of a number of anti-discrimination tests. ${ }^{37}$ For example, a top-heavy defined contribution plan generally must provide non-key employees with contributions equal to $3 \%$ of compensation. ${ }^{38}$

The anti-discrimination rules are supported by detailed participation and coverage requirements. ${ }^{39}$ Absent such requirements, an employer could maintain nominal compliance with the anti-discrimination rules simply by excluding non-highly compensated employees from plan coverage. Instead, beginning in 1989, a plan must benefit the lesser of 50 employees or $40 \%$ of all employees. ${ }^{40}$ In addition, a plan must benefit at least $70 \%$ of all rank and file employees, or meet certain other statutory standards. ${ }^{41}$ Part-time employees, employees under the age of 21 , and employees with less than a specified number of years of service may be excluded from the coverage determination. ${ }^{42}$ The exclusion of new and part-time employees, and the non-inclusive nature of the coverage tests, is

3s A "key employee" is defined, in general, as an officer with annual compensation in excess of $\$ 45,000$, an employee with annual compensation in excess of $\$ 45,000$ with at least the tenth largest ownership interest in the employer of any employee, a $5 \%$ owner of the employer, or a $1 \%$ owner of the employer with an annual compensation in excess of $\$ 150,000$. \& 416(i)(1).

${ }^{36} \S 416(\mathrm{~g})$.

37 $\S 416(\mathrm{a})-(\mathrm{d})$.

38 $\$ 416$ (c)(2)(A). The $3 \%$ contribution is determined without regard to social security contributions. If no key employee receives contributions equal to $3 \%$ of compensation, then the plan may retain tax-qualified status so long as the ratio of contributions to compensation for rank-and-file employees is as great as the highest ratio of benefits to compensation received by any key employee. $\$ 416$ (c)(2)(B).

${ }^{39} \S \S 401(\mathrm{a})(26), 410$.

$10 \S 401(a)(26)$.

$41 \S 410(\mathrm{~b})$. The other statutory standards are as follows: (i) the proportion of rankand-file employees covered must be at least $70 \%$ as great as the proportion of highly compensated employees covered; or (ii) the classification of beneficiaries must be found to be non-discriminatory by the Secretary of the Treasury, and the average benefit percentage for rank-and-file employees must be at least $70 \%$ of the average benefit percentage for highly compensated employees. Id. The factors which might lead a plan to be considered nondiscriminatory by the Secretary of the Treasury are discussed in Dunkle, Guide to Pension Plans (cited in note 1).

$12 \S 416(\mathrm{a})(1)$. 
generally thought to permit significant deviations from the rule of proportionate equality. ${ }^{43}$

The anti-discrimination rules are also supported by aggregation and vesting provisions. ${ }^{44}$ The aggregation provisions define the organization with respect to which discrimination is to be measured. In the past, employers often circumvented anti-discrimination rules by establishing a separate organization to employ highly compensated workers. The new organization would adopt a liberal pension plan and would contract with the parent organization for services and materials. ${ }^{45}$ Under current law, all organizations are subject to aggregation provisions, and statutorily defined "service organizations" are subject to particularly inclusive aggregation provisions. $^{46}$

The vesting provisions prevent the loss of accumulated benefits upon voluntary or involuntary departure. Absent such provisions, an employer could set up a nominally non-discriminatory plan which, because of high turnover of rank-and-file workers, would primarily benefit highly compensated employees. ${ }^{47}$ Instead, beginning in 1989, a plan will generally have to offer complete vesting of accrued benefits after 5 years, or partial vesting after 3 years and complete vesting after 7 years. ${ }^{48}$ The failure to require immediate vesting, like the failure to require participation of all employees, is generally thought to permit significant deviation from the anti-discrimination rules. ${ }^{48}$

The anti-discrimination rules are extraordinarily complex.

4s President's Commission, Coming of Age at 27 (cited in note 20); Altman, 42 Tax L.Rev. at 460 n.112, 471 (cited in note 27); Halperin, Tax Policy and Retirement Income at 165-68 (cited in note 27).

"Specific aggregation provisions are contained within provisions governing participation and vesting requirements; more general aggregation provisions are contained in $\S \S 414(\mathrm{~b}),(\mathrm{m})-(\mathrm{n})$.

15 Both the problems caused by such "loan out" corporations and the legislative response to such problems are discussed in Philip S. Neal and Harry J. Conaway, New Section 414(m) Limits Qualified Plan Abuse By Affiliated Service Organizations, 54 J.Tax'n. 258 (1981).

is See $\S \S 414(\mathrm{~m})-(\mathrm{n})$.

47 The vesting provisions also serve a consumer protection function. See the text accompanying notes $67-69$ below.

$18 \S 411(\mathrm{a})$. A plan will fail to achieve tax-qualified status notwithstanding compliance with $\S 411$ (a) if there is a pattern of abuses (such as dismissal prior to vesting) tending to discriminate in favor of highly compensated employees, or if there is any other reason to believe the accrual of benefits or forfeitures will discriminate in favor of highly compensated employees. $\S 411(d)(1)$.

4 See Altman, 42 Tax L.Rev. at 498-500 (cited in note 27); Graetz, 135 U.Pa.L.Rev. at 884-887 (cited in note 6). 
Many statutory provisions and terms require detailed regulation, ${ }^{\text {so }}$ and special rules are required for a wide array of non-standard business arrangements, such as pension plans jointly adopted and funded by more than one employer. ${ }^{51}$ Further complexity is introduced by the legislative desire to differentiate among different classes of plans and to treat certain types of employers and employees differently. For example, seasonal, maritime, and tax-exempt employers each face a special set of participation and vesting provisions. ${ }^{52}$ The proliferation of these rules and regulations has removed pension plan administration from the ambit of most attorneys and has dramatically increased the costs of plan administration.

The complexity of the anti-discrimination provisions makes it impossible to predict the precise effect they have on pension plans. The broad effect of these provisions, however, is easily summarized. In general, the anti-discrimination provisions require proportionately equal benefits for highly compensated and non-highly compensated employees. In some cases, due primarily to the integration rules and the gaps in participation and vesting, the proportionality standard is relaxed. To organizations subject to the topheavy rules, however, a tighter standard is applied. In all cases, the anti-discrimination provisions reduce the permissible wage-based disparity in pension benefits and contributions.

\section{The Problem of Justification}

The scope and significance of the anti-discrimination rules might suggest the existence of a good deal of legislative debate or outside commentary. In fact, surprisingly little has been written or said about the intent or justification of the rules.

The rules appear to have originated in 1937 hearings before a

so The vesting provisions, for example, set forth alternative schedules under which accrued benefits must become nonforfeitable. In defined benefit plans, which promise employees a fixed amount upon retirement or an amount upon retirement contingent upon certain factors (such as average salary or years of service), the determination of the accrued benefit at any given time may be quite difficult. The Internal Revenue Service has issued a ten-page regulation which requires that one of three methods be used to determine the accrued benefit. 26 C.F.R. $\$ 1.411(b)-1$ (1987).

${ }^{31} \S 414(f)$.

$52 \S 410(a)(3)(B)$ (in any seasonal industry where the customary period of employment is less than 1,000 hours during a calendar year, the term "year of employment" is determined under regulations prescribed by the Secretary of Labor); $\$ 410(a)(3)(D)$ (in maritime industries, 125 days of service during a calendar year are sufficient to constitute a year of employment); $\$ \S 410(\mathrm{c}), 411$ (e) (exceptions for government pension plans or certain nonprofit organizations). 
specially convened Joint Committee on Tax Evasion and Avoidance. Pensions at that time were taxed in the same manner as they are taxed today: contributions were deductible to the employers, and employees were taxed on contributions and pension earnings only upon withdrawal. ${ }^{53}$ These favorable provisions, then as now, made pensions particularly attractive to highly taxed employees and contributed to the development of plans designed exclusively for these employees. ${ }^{54}$ Noting this development, the Treasury argued that the original intent of the pension provisions-"to encourage a sort of social security on the part of individual corporations" 5 _ had been "twisted into a means of tax avoidance by the . creation of pension trusts which include as beneficiaries only small groups of officers and directors who are in the high income brackets."

The Treasury recommended that the then-current requirement that tax-qualified plans benefit "some or all" employees be modified to require coverage of a "reasonable number" of employees. $^{57}$ The Treasury's recommendation was set forth in written supplemental materials offered to the Committee and was discussed only in passing in five days of hearings. ${ }^{58}$ The recommenda-

${ }^{53}$ Provisions deferring taxation on pension contributions and the interest earned on those contributions, until the receipt of benefits by the employee, were first passed in 1926. Revenue Act of 1926 \& 219(f), Pub.L.No. 69-20, 44 Stat. 9, 33-34 (1926). Profit-sharing plans, considered as pensions for the purpose of this article, were granted this favorable tax treatment in 1921. Revenue Act of 1921 § 219(f), Pub.L.No. 67-98, 42 Stat. 227, 247 (1921). Specific authority for deductibility of pension contributions in the year earned was granted in 1928. Revenue Act of 1928 § 23(a), (q), Pub.L.No. 70-562, 45 Stat. 791, 799, 802 (1928). Prior to 1928, employer deductibility was apparently allowed as a matter of administrative practice or accepted statutory construction. See William J. Chadwick and David S. Foster, Federal Regulation of Retirement Plans: The Quest for Parity, 28 Vand.L.Rev. 641, 647-50 (1975).

s4 The growth of "keymen" policies is discussed in articles submitted by the Treasury to the Committee. Tax Evasion and Avoidance, Hearings before the Joint Committee on Tax Evasion and Avoidance, 75th Cong. 1st Sess. 243-288 (1937)("Joint Commitee Hearings").

ss Id. at 306. The Treasury's belief that the provisions were enacted as an explicit subsidy to pensions is not directly supported by the legislative history. It is possible that at the time of their passage, the pension provisions were thought to comport with neutral principles of taxation, as discussed briefly in Altman, 42 Tax L.Rev. at 446-50 (cited in note 27). Under the then-current "constructive receipt" doctrine, work-related compensation was often not taxed until received in cash form. In an era of low interest rates and low tax rates, the problems caused by deferral of taxation may have been regarded as minor.

so Joint Committee Hearings at 5 (cited in note 54).

67 Id. at 294.

s8 The pension trusts testimony sparked only one extended colloquy between the Treasury and the Committee, and that concerned the question of whether or not such trusts were irrevocable. Id. at 307-08. 
tion did not appear to provoke outside commentary and was not incorporated in the Committee's recommendations. ${ }^{59}$

In 1942, the heart of the current anti-discrimination regimen was proposed by the Treasury and passed by Congress. ${ }^{60}$ In support of the legislation, the Treasury reiterated its belief that the subsidy inherent in the pension provisions had led to plans which gave too many benefits to highly compensated employees and too few benefits to rank-and-file employees. ${ }^{61}$ The legislation was also described as one of a number of necessary war-related revenue measures which would produce an estimated $\$ 100,000,000$ in annual receipts. ${ }^{62}$

The anti-discrimination proposals were noted in the press and discussed in hearings. ${ }^{63}$ Debate and commentary on the measure, however, centered on a side issue: whether the vesting provisions proposed by the Treasury (and ultimately rejected by Congress) would trigger the termination of the American Telephone and Telegraph Company pension plan. ${ }^{64}$ There was no discussion of the merits to a rule of proportionate equality of benefits or the effect of such a rule on wages rates. In a statement consistent with the position espoused by the Treasury but otherwise unilluminating, the House Committee Report explained that the measure was intended "to insure that stock bonus, pension, or profit-sharing plans

s9 The Committee's Report, like the oral and written testimony presented to the Committee, centered on the tax avoidance made possible through personal holding companies, multiple trusts, alien status, and related party transactions. Report of the Joint Committee on Tax Evasions and Avoidance, 75th Cong., 1st Sess., in 81 Cong.Rec. 8246-53 (Aug. 5, 1937).

${ }^{60}$ Revenue Act of $1942 \S 162$, Pub.L.No. 77-753, 56 Stat. 798, 862-67 (1942), revised by subsequent legislation. The Treasury proposals included the requirement that the ratio of benefits to salary for rank-and-file employees be at least as great as for highly compensated employees. The proposals also included vesting and coverage provisions. Congress rejected the vesting provisions and added a form of the present integration requirements before enacting the proposals into law.

${ }^{61}$ See Revenue Revision of 1942, Hearings on H.R. 7378 before the House Committee on Ways and Means, 77th Cong., 2nd Sess. 2405 (1942)("House Hearings")(testimony of Randolph Paul, Tax Advisor to the Secretary of the Treasury).

${ }^{62}$ Id. at 10.

${ }^{63}$ See generally, id.; Revenue Act of 1942, Hearings on H.R. 7378 before the Senate Committee on Finance, 77th Cong., 2nd Sess. (1942).

${ }^{64}$ A representative of the American Telephone and Telegraph Company testified at the hearings that the vesting provisions advocated by the Treasury would cause the immediate termination of the company's pension plan. House Hearings at 2416. A number of American Telephone and Telegraph Company employees and employee representatives testified in opposition to the measure. These individuals comprised a near majority of individuals who commented on the measure before the legislative committees. See Id. at 2410, 2415-6, 2451, $2454,2457,2495,2500-01$. Vesting requirements similar to those proposed by the Treasury in 1942 were enacted into law in 1974. 
are operated for the welfare of employees in general, and to prevent the trust device from being used for the benefit of shareholders, officials, or highly paid employees . . . ."

Since 1942, the anti-discrimination rules have been strengthened through the enactment of vesting, aggregation, and top-heavy provisions, and through amendments to the coverage and integration provisions..$^{68}$ However, the more recent legislative history says almost nothing about the purpose or efficacy of the anti-discrimination regimen.

The vesting provisions, for example, were enacted as part of the Employee Retirement Income Security Act of 1974 and were supported on consumer protection grounds. Benefits from pensions at that time often did not vest for thirty or forty years; in some cases pensions did not vest until retirement. Employees who voluntarily or involuntarily left employment before their pension had vested forfeited all benefits. Congress believed that many employees were not aware of, or systematically underestimated, the possibility of forfeiture. ${ }^{67}$ This lack of information interfered with an employee's ability to bargain over her compensation package and led to undersaving. The vesting provisions were intended to conform forfeiture provisions to employee perceptions. While the requirements also served to widen the scope of coverage of rank-andfile workers, they were not justified on that ground. ${ }^{68}$ As stated by

6s Detailed Discussion of the Technical Provisions of H.R. 7378, H.R.Rep.No. 2333, 77th Cong., 1st Sess. 372, 450 (1942).

¿s See Tax Reform Act of $1986 \S \S 1111-1120$, Pub.L.No. 99-514, 100 Stat. 2085 (1986); Deficit Reduction Act of $1984 \S \S 524,526,527$, Pub.L.No. 98-369, 98 Stat. 494, 872-73, 87476 (1984); Retirement Equity Act of $1984 \S \S 202-3$, 205, 301, Pub.L.No. 98-397, 98 Stat. 1426, 1436-45, 1449, 1450-51 (1984); Tax Equity and Fiscal Responsibility Act of $1982 \S \S$ 237-40, 246, 248, 249, Pub.L.No. 97-248, 96 Stat. 324, 511-20, 525, 526-28 (1982); Revenue Act of 1978 \& 152, Pub.L.No. 95-600, 92 Stat. 2763, 2797-2800 (1978); Employee Retirement Income Security Act of $1974 \S \S 1011-1017$, Pub.L.No. 93-406, 88 Stat. 829, 898-935 (1974); Revenue Act of $1964 \S 220$, Pub.L.No. 88-272, 78 Stat. 19, 58-63 (1964).

${ }^{67}$ See Private Welfare and Pension Plan Legislation, Hearings on H.R. 1045, 1046, and 16462 before the General Subcommittee Labor of the House Committee on Education and Labor, 91st Cong., 1st and 2d Sess. 252 (1970)("House Labor Subcommittee Hearings")(statement of Representative Roman C. Pucinski)("The average worker thinks that he has some kind of a security, when actually he doesn't").

88 The distinction between the vesting and other provisions of ERISA and the goals of the anti-discrimination provisions was explicitly acknowledged in the legislative hearings. See House Labor Subcommittee Hearings at 81 (cited in note 67) (statement of Stanley Surrey, former Assistant Secretary for Tax Policy)("The present standards for qualifying for the tax benefits provided for private pension plans are mainly concerned with preventing discrimination in favor of highly paid employees. . . . On the other hand, the requirements for vesting, funding, and termination protection contained in this bill, in combination, seek to fulfill and secure an employee's pension expectations from his employer"). 
the Chairman of the Senate Committee on Labor and Public Welfare, the purpose of the bill was to "safeguard the pension expectations of the American workers."

The top-heavy provisions were added by a Joint Committee on Taxation to a comprehensive tax reform measure after that bill had passed both houses of Congress. ${ }^{70}$ The short time between proposal and enactment appears to have precluded significant discussion.

The aggregation rules and the various amendments to other aspects of the anti-discrimination requirements were proposed and passed as minor adjustments to an accepted regimen. ${ }^{71}$

The anti-discrimination rules have been the subject of a voluminous amount of legal commentary. ${ }^{72}$ Nearly all of this literature, however, is written by and for pension specialists. The literature purports to help planners understand and to some extent circumvent the anti-discrimination rules but does not examine the social utility of these rules. Among the scholarly articles, only a handful discuss the anti-discrimination provisions in any detail. These articles have examined the combined use of the tax deferral on pension savings provisions and the anti-discrimination provisions as a means of promoting worker security. ${ }^{73}$

${ }^{69}$ Statement of Senator Harrison A. Williams, Jr., in Richard L. Madden, Pensions Reform Passed by Senate and Sent to Ford, N.Y.Times at 1 (Aug. 23, 1974). See also Retirement Income Security for Employees Act, 1972, Hearings on S. 3598 before the Subcommittee on Labor of the Senate Committee on Labor and Public Welfare, 92d Cong., 2d Sess. 91 (1972)(statement of Senator Harrison A. Williams, Jr.) ("[t]he only goal of this legislation is to ensure that American workers receive the pension benefits ... which they have been promised").

70 Tax Equity and Fiscal Responsibility Act of 1982 at $\S 240$ (cited in note 66).

${ }_{71}$ The enactment of aggregation rules and the amendment of other aspects of the antidiscrimination provisions assume, rather than question, the goal of proportionate equality. The Tax Reform Act of 1986, for example, significantly amended the coverage requirements on the theory that "the prior-law coverage tests for qualified plans . . . were not sufficient to ensure nondiscriminatory coverage of nonhighly compensated employees." Staff of the Joint Committee on Taxation, General Explanation of the Tax Reform Act of 1986671 (1987).

${ }^{72}$ One index to federal tax articles contains seventeen single-spaced pages of recent articles on pension and profit-sharing articles. Most of the listed articles involved either the anti-discrimination requirements or the supporting coverage, vesting and aggregation rules. Gersham Goldstein, Index to Federal Tax Articles, 3-245 to 3-262 (Cum.Supp. Fall 1987).

${ }^{73}$ In Discrimination Rules for Qualified Retirement Plans: Good Intentions Confront Economic Reality, 70 Va.L.Rev. 419 (cited in note 31), Professor Wolk provides a brief but lucid explanation of the relationship between wealth, pensions, and employee choice. He concludes that the pension savings and anti-discrimination provisions comprise a "blunt" instrument with which to ensure adequate retirement income and instead advocates a mandatory private pension system. In Rethinking Retirement Income Policies: Nondiscrimination, Integration and the Quest for Worker Security, 42 Tax L.Rev. 433 (cited in note 27), 
This article uncouples the anti-discrimination provisions from the pension savings provisions and examines the desirability of the former alone. This approach has several advantages. First, the anti-discrimination provisions and pension savings provisions are both extremely complex and any single article that attempts an undifferentiated analysis of both provisions must necessarily make important and limiting simplifying assumptions. ${ }^{74}$ The more exclusive focus adopted here should permit a greatly expanded examination of the possible justification for the anti-discrimination rules. Second, as discussed in Part VI, analysis of the pension savings provisions raises nearly intractable theoretical issues. A scholarly consensus on the desirability of these provisions is unlikely to develop, and even if such agreement were reached, political change in this area seems unlikely. The anti-discrimination requirements, in contrast, seem much more amenable to consensus and change. This is especially so because, as this article emphasizes, every goal served by the requirements could be better served through other measures.

\section{A Welfare-Based JUStification for the ANTI-Discrimina- TION REQUIREMENT}

The anti-discrimination requirements might be justified as a way to increase the welfare of rank-and-file employees. The provisions will tend to increase the pension benefits received by rankand-file employees. This increase might be supposed to be financed by employers (or perhaps, through higher prices, by consumers) and the resultant wealth transfer to affected workers may be

Professor Altman provides a superb description of the operation and historical development of the pension savings and anti-discrimination provisions. She advocates retention of the anti-discrimination provisions and strengthening of the accompanying vesting and coverage provisions to the alternative of a mandatory pension. In The Troubled Marriage of Retirement Security and Tax Policies (cited in note 6), Professor Graetz discusses the full panoply of tax provisions which affect retirement security; the anti-discrimination provisions are noted only in passing. Graetz appears to favor strengthening the anti-discrimination provisions as a "second-best" alternative to a mandatory private pension. In his scholarship and Congressional testimony, Professor Halperin has discussed or touched upon many of the themes of this article. See Halperin, Tax Policy and Retirement Income at 161 (brief discussion of paternalistic basis of anti-discrimination requirements), 192 (effect of requirements on wages)(cited in note 27). See also, Daniel I. Halperin, Retirement Security and Tax Equity: An Evaluation of ERISA, 17 B.C.Ind. \& Comm.L.Rev. 739 (1976).

${ }^{3}$ Professors Altman and Wolk, for example, assume that the justification for pension savings provisions must rest on retirement security grounds, and that non-redistributive government intervention in the wage mix is desirable. Altman, 42 Tax L.Rev. 433 (cited in note 27); Wolk, 70 Va.L.Rev. 419 (cited in note 31). The structure of their enterprise precludes detailed discussions of these assumptions; both are controversial. 
thought desirable. Congress has at times indicated its belief that employer-provided pension contributions constitute a form of wealth transfer, and this belief appears to be widely shared. ${ }^{\mathbf{7 5}}$

This section utilizes a simple partial equilibrium model to examine the assumption that a mandated increase in pension benefits will increase employee welfare. The intuition behind the model is straightforward. Additional pension benefits required by the anti-discrimination provisions will reduce the amount of cash salary employers are willing to pay for a fixed quantity of labor by the cost of the additional benefits. The anti-discrimination requirements will have another effect as well. In the absence of government intervention, employers and employees will agree upon the ratio of benefits to salary which maximizes the perceived value of the compensation package to the employees. The additional pension benefits required by the anti-discrimination provisions, together with the reduction in cash salary, will change that ratio and reduce the perceived value of the compensation package. The additional benefits will be worth less to the employees than the amount of cash by which their salary has been reduced or the cost of the benefits to the employer.

A labor supply model. The effect of the anti-discrimination provisions on rank-and-file employees may best be understood by first examining the supply and wages of such employees in a world without pensions. Assume that, as depicted by supply curve $S$ in Figure 1 , the supply of such labor is 35,000 at $\$ 10,000$ and then rises as the wage rate rises. Demand for such labor, as depicted by demand curve D in Figure 1, is 55,000 at $\$ 10,000$ and then falls as wages rise. Supply and demand balance at 45,000 employees and $\$ 20,000$.

Assume now that the full panoply of pension plans are made available to employees, and that Congress enacts the current favorable tax treatment of pension contributions. Assume that the first $\$ 1,000$ of tax-deferred contributions are worth $\$ 2,000$ in currently-taxed wages to each rank-and-file employee. The second $\$ 1,000$ of contributions, however, are worth only $\$ 500$ to each employee. The decline in value reflects the employees preference for

75 See, for example, Staff of the Joint Committee on Taxation, General Explanation at 634 (cited in note 71) (plans which require employee contributions restricted on the assumption that such plans shift costs from employers to employees); Louis Harris and Associates, Inc., Retirement and Income vi, 31, 80-86 (1984) (workers favor mandatory employer contributions over increased employee contributions, apparently on the assumption that the cost of employer contributions is not reflected in lower cash wages). 
current over future income. Pension contributions are illiquid and, in many cases, cannot be "borrowed out" by the employee, or serve as collateral for a commercial loan. ${ }^{76}$ The employees may feel the existing level of pension benefits will provide sufficient retirement income; the preference for current income also might be attributable to necessary personal or family expenses, investment opportunities which require cash, or simply the desire to enjoy the fruits of one's labor now rather than later. At some point, virtually all individuals will prefer current income to future pension benefits.

It will be in the interests of employees and employers to structure the compensation to include $\$ 1,000$ of pension contributions. These contributions will be worth $\$ 2,000$ to the employees, for a net gain of $\$ 1,000$. This gain may then be split between the contracting parties. The precise manner in which the benefits will be split will depend upon the supply and demand curves. The payment of $\$ 1,000$ of pension contributions will reduce by $\$ 1,000$ the amount of cash compensation employers are willing to pay for a given quantity of labor. The demand curve D depicted in Figure 1 will shift downwards by $\$ 1,000$; the new curve is depicted as $D^{\prime}$. The receipt of $\$ 1,000$ in pension contributions will reduce by $\$ 2,000$ the amount of cash compensation required to induce a given number of employees to work. The supply curve $\mathrm{S}$ depicted in Figure 1 will shift by $\$ 2,000$; the new curve is depicted as S'. Supply and demand now intersect at approximately $\$ 18,500$ cash and $\$ 1,000$ pension benefits. The cost of labor to employers has declined from $\$ 20,000$ to $\$ 19,500$ ( $\$ 18,500$ plus $\$ 1,000$ pension expense). The value of the wage package has increased from $\$ 20,000$ to $\$ 20,500$ ( $\$ 18,500$ cash plus pension benefits worth $\$ 2,000)$. Here, employers and employees shared the $\$ 1,000$ surplus equally.

It may now be useful to imagine the effect of the anti-discrimination requirements on the same labor market. We have seen that, absent such requirements, it will be in the employer's interest to structure the compensation mix of rank-and-file workers in the manner desired by those workers. Here, rank-and-file workers desire contributions equal to about $5 \%$ of cash salary. If highly compensated employees desire an equivalent or lesser percentage of their compensation in the form of pension benefits, the anti-discrimination provisions will have no effect. It is generally expected,

${ }^{78}$ See $\$ 72(t)$ (a $10 \%$ penalty is imposed on the taxable portion of pension plan distributions unless the employee has reached age $59 \frac{1}{2}$, died, or been disabled); $\$ 72(p)$ (loans based on future pension benefits will be treated as distributions unless certain dollar and use limitations are met). 
Figure One: LABor Supply Model:

No ANTI-DISCRIMINATION REQUIREMENTS ${ }^{77}$

FIGURE ONE

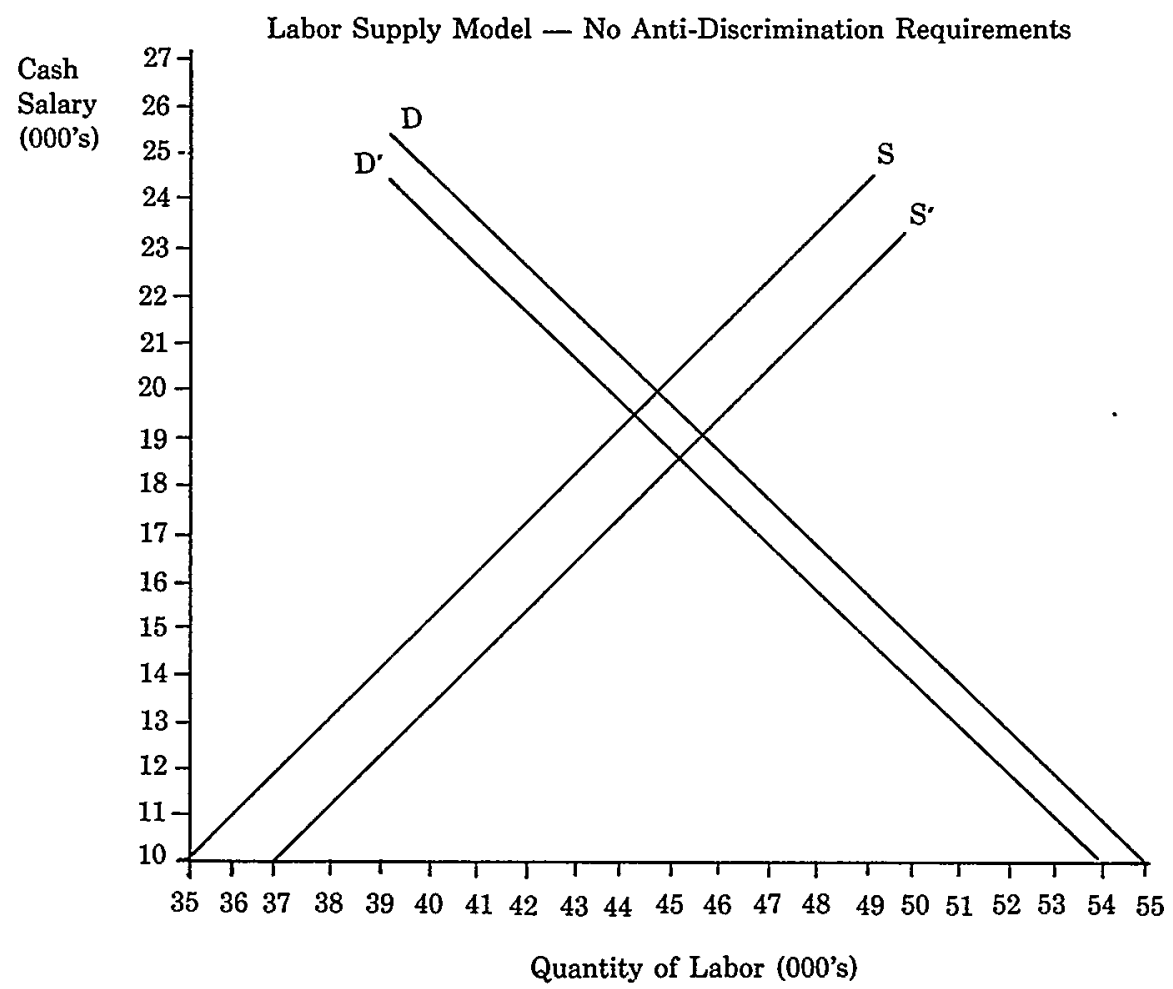

however, that the desired percentage of compensation to be received in the form of pension benefits will be greater for highly compensated employees than for rank-and-file workers. ${ }^{78}$ In general, highly compensated employees will save a larger percentage of their income than will rank-and-file employees. ${ }^{79}$ Moreover, highly compensated employees often will face higher tax brackets and will therefore receive a larger advantage from the favorable tax treat-

${ }^{77} \mathrm{~S}$ and $\mathrm{D}$ are the supply and demand curves, respectively, prior to the introduction of pensions. $S^{\prime}$ and $D^{\prime}$ are the supply and demand curves, respectively, after the introduction of tax-favored pensions. The aggregate cost of the compensation package after the introduction of pensions may be determined by adding the $\$ 1,000$ cost of pension benefits to the $\$ 18,500$ cash salary reached at the intersection of $S^{\prime}$ and $D^{\prime}$. The value of the compensation package to employees after the introduction of pernsion benefits may be determined by adding the $\$ 2,000$ value of the pension contributions to the $\$ 18,500$ cash salary reached at the intersection of $S^{\prime}$ and $D^{\prime}$. The supply and demand curves depicted are hypothetical and have been drawn in a simplified manner to aid comprehension. 20).

${ }^{78}$ See President's Commission on Pension Policy, Coming of Age at 35 (cited in note

79 See Altman, 42 Tax L.Rev. at $435-36$ (cited in note 27). 
ment of pension benefits.

Assume, therefore, that the highly compensated employees desire pension contributions equal to $12 \%$ of their cash compensation. The employer must now balance the competing demands of different classes of workers: the anti-discrimination requirements do not permit differential levels of pension benefits. Assume that aggregate labor costs are minimized if the employer sets the pension contribution level at $10 \%$. Pension contributions for rankand-file workers now stand at about $\$ 2,000 .^{80}$ The new proportion of salary received in the form of pension contributions is higher than that desired and otherwise received by the rank-and-file workers. Here, as discussed above, the additional $\$ 1,000$ of contributions is worth only $\$ 500$ to the workers.

The contracting parties may wish to escape the anti-discrimination requirements and restructure the compensation mix to increase the proportion of cash compensation. However, this alternative is impossible, because the requirements cannot be waived.

The effect of the anti-discrimination requirements will depend on the supply and demand curves. The additional $\$ 1,000$ of benefits will reduce the amount employers are willing to pay for a given quantity of labor by $\$ 1,000$. This will shift the demand curve $D^{\prime}$ downward; the new curve is depicted as $D^{\prime \prime}$ in Figure 2. The additional benefits will reduce the amount of cash salary which will induce a given number of employees to work by $\$ 500$. This will shift the amount of labor provided at a given salary upward (but by a lesser amount than the demand curve $D^{\prime}$ has been shifted downward). The new supply curve is depicted as S" in Figure 2. Supply and demand now balance at $\$ 17,750$ cash and $\$ 2,000$ pension contributions.

The additional benefits required by the anti-discrimination provisions have produced four effects. First, the perceived value of the wage package has fallen from $\$ 20,500$ to $\$ 20,250$. Second, the labor costs have risen from $\$ 19,500$ to $\$ 19,750$. Third, employment has dropped from its previous high of 45,500 . Finally, the favorable tax treatment granted to the additional benefits has reduced government tax revenues.

The process by which the $\$ 500$ gap between the cost and perceived value of the additional benefits is shared by employers and employees may be understood as follows: If the supply of labor were fixed, employers could reduce cash salary by the cost of the benefits. Employees would face a reduction in cash salary of $\$ 1,000$ and receive benefits valued at only $\$ 500$. In that case, the differ-

${ }^{80}$ The actual amount of benefits will initially be $\$ 1,850$ (10\% of current cash compensation) and then will be adjusted as the imposition of the anti-discrimination requirements change the relative wages. 
ence between the cost and perceived value of the benefits would be borne entirely by employees. In practice, however, supply is rarely fixed, and any attempt to reduce wages by the full $\$ 1,000$ cost of the benefits would reduce supply to the point at which it falls below demand. Supply and demand will balance only if the employers accept a net increase in labor costs of $\$ 250$, and, in effect, "charge" employees $\$ 750$ for benefits which cost $\$ 1,000 .{ }^{81}$ Here, employers and employees split the $\$ 500$ loss.

\section{Figure Two: Labor Supply Model: ANTI-Discrimination Requirements in EFFECT ${ }^{82}$}

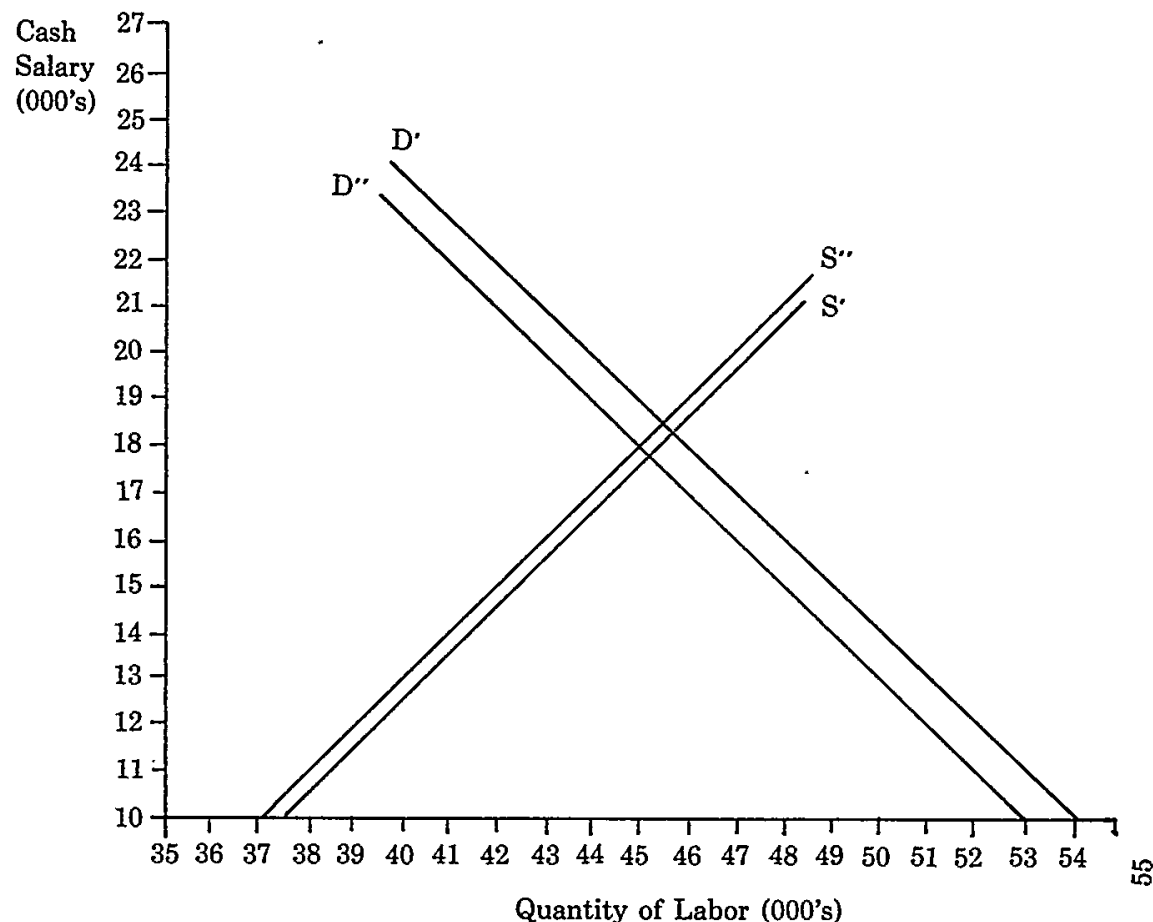

81 In a similar fashion, since demand is not fixed, any attempt to require the employers to reduce cash wages by only the $\$ 500$ value of the benefits would reduce demand to the point at which it fell below supply.

${ }^{82} S^{\prime}$ and $D^{\prime}$ depict the supply and demand for labor, respectively, in a world with taxfavored pensions but without anti-discrimination provisions. The intersection of $S^{\prime}$ and $D^{\prime}$ produces cash salary of $\$ 18,500$ and pension benefits of $\$ 1,000$. The compensation mix costs the employer $\$ 19,500$ and is valued at $\$ 20,500$. S" and $D^{\prime \prime}$ depict labor supply and demand in a world in which the anti-discrimination provisions require an additional $\$ 1,000$ of pension benefits which are valued at only $\$ 500$ by employees. $S^{\prime \prime}$ and $D^{\prime \prime}$ intersect at $\$ 17,750$. 
The effects of the anti-discrimination provisions depend critically on the responsiveness, or elasticity, of the supply and demand curves. Here, supply and demand were equally responsive to changes in price and the inefficiency introduced by the anti-discrimination provisions was shared equally by employees and employers. If supply were more responsive to changes in price, the inefficiency would be borne largely by employers; if demand were more responsive to changes in price, the inefficiency would be borne largely by employees. ${ }^{83}$ But so long as an increase in wages increases supply and reduces demand, benefits attributable to the anti-discrimination requirements would to some degree decrease both employee and employer welfare. ${ }^{84}$

All analysis based on the partial equilibrium model assumes that employers and employees are aware of and respond to changes in pension cost and value. Pensions are extremely complex financial instruments, and minor changes in the anti-discrimination requirements may have little or no effect on the labor supply or wages. Even major changes in the requirements, or in any other aspect of pension cost or value, may not affect the labor supply or wages for a long time period. Moreover, employers may be responsive to aggregate employee pension costs but may not vary wages

The compensation mix costs the employer $\$ 19,750$; the compensation mix is valued by the employee at $\$ 20,250$. The supply and demand curves depicted are hypothetical and have been drawn in a simplified manner to aid comprehension.

${ }^{83}$ The inefficiency introduced by the anti-discrimination requirements acts as a form of payroll tax. A discussion of the incidence of the latter tax is found in Robert Boadway, Public Sector Economics 378-379 (1979).

84 In some cases, of course, these conditions will not hold and different results may apply. One such case is that presented when the supply of labor increases as wages fall. This seemingly counterintuitive result could arise because of the so-called "income effect." At low wages, the value of an additional dollar of income and the consumption it may bring is very great; an employee may feel she "needs" to work (or work overtime) to maintain a desired standard of living. Conversely, at high wages, the same employee may decide she can "afford" additional leisure.

If the supply of labor increases as wages fall, all of the efficiency costs of the antidiscrimination requirements will be borne by the employees and the employer's labor costs will actually fall. This anomalous result obtains because the effective decline in the wage rate induces employees to increase the aggregate work effort; consequently, the employers are able to attract an acceptable supply of labor even at lower wages.

A second plausible case in which the anti-discrimination requirements do not reduce both employee and employer welfare is that presented in a monopsonistic market; that is, a market characterized by a single employer. In such a market, the price may be artificially restricted by the employer. Depending on the market characteristics, an inefficiency introduced by mandatory benefits may be absorbed entirely by the employer; employees who receive benefits which cost $\$ 1,000$ but which are valued at $\$ 500$ may find their compensation reduced by $\$ 500$. See generally Boadway, Public Sector Economics at 441 (cited in note 83) (discussion of effects of monopoly and monopsony on labor supply). 
to reflect the pension cost of particular employees. ${ }^{85}$ The conclusions drawn from the model also assume that employees accurately perceive their own welfare interests-an assumption which is explored in greater detail later in this article.

The conclusions drawn from the model, finally, are sensitive to the assumption that all rank-and-file employees place the same value on pension benefits. The labor supply and wage rate reflect the desires of marginal employees and employers. If more stable, infra-marginal employees place a lower value on pension benefits than marginal employees, the perceived welfare loss will be increased. If, as is more likely, infra-marginal employees place relatively high value on pension benefits, the welfare loss will be reduced. ${ }^{86}$

There have been no empirical or even theoretical studies of the effects of the anti-discrimination requirements. ${ }^{87}$ However, the aggregate labor supply is generally thought to be inelastic. ${ }^{88} \mathrm{~A}$ number of empirical studies also have concluded that, when other variables are held constant, higher benefits are associated with lower cash salaries. ${ }^{89}$ These two sets of studies suggest that the costs of the anti-discrimination requirements are initially borne by affected employees. That appears to be the conclusion of union leaders; in testimony before Congressional committees, union representatives have generally opposed legislative interference in the compensation mix of rank-and-file workers. ${ }^{90}$

${ }^{85}$ See, for example, Jeremy Bulow and Wayne Landsman, The Relationship between Wages and Benefits, in Bodie and Shoven, eds., Pensions, Labor, and Individual Choice at 379 (cited in note 7) (Stanford University does not take into account pension costs in negotiating individual wage package, though such costs may affect aggregate wages).

${ }^{86}$ The possibility that valuation differences between marginal and infra-marginal employees may make government intervention in contract desirable is discussed in Mark Kelman, A Guide to Critical Legal Studies 186 (1987).

${ }^{87}$ In a recent essay, however, economist Richard Ippolito has stated that "discrimination rules have virtually ensured that inefficient wage contracts will be negotiated." Ippolito, Pensions and Economics at 33, 42 (cited in note 8). Ippolito's brief discussion of the issue suggests his conclusion is based on an analysis similar to that presented in this section. Id. at 42 .

${ }^{88}$ Anthony B. Atkinson and Joseph E. Stiglitz, Lectures on Public Economics 48-58 (1980); Joseph A. Pechman, Who Paid the Taxes, 1966-85? 27-31 (1985).

${ }^{89}$ See, for example, Ronald G. Ehrenberg and Robert S. Smith, A Framework for Evaluating State and Local Government Pension Reform, in Peter Mieszkowski and Georg E. Peterson, eds., Public Sector Labor Markets 103, 110, 119-23 (1981); Ronald G. Ehrenberg, Retirement System Characteristics and Compensating Wage Differentials in the Public Sector, 33 Indus. \& Lab.Rel.Rev. 470 (1980).

${ }^{80}$ See Private Welfare and Pension Plan Legislation, Hearings on H.R. 1045, H.R. 1046, and H.R. 16462 before the General Subcommittee on Labor of the House Committee on Education and Labor, 91st Congress, 1st and 2d Sess. 461 (1970) (letter from Jacob 
General Equilibrium Effects. The anti-discrimination provisions will affect rank-and-file employees in ways not explicitly considered in a partial equilibrium model, and the change in economic behavior of these employees will affect other segments of the economy ${ }^{91}$ As noted above, anti-discrimination requirements do not affect unionized firms, or firms which do not have pension plans; the impact of the requirements on other firms will depend on the interplay between the various statutory formulae and the interests of the classes of workers. Rank-and-file employees who perceive their compensation reduced by the anti-discrimination requirements may move to firms not subject to those requirements or to firms with respect to which the requirements have a lesser effect.

More generally, the anti-discrimination requirements might produce a shift of labor and capital which will affect all labor and capital in varying degrees. For example, the anti-discrimination requirements might cause a substitution of capital for labor in immediately affected industries; this substitution would cause labor to shift to unaffected industries. The influx of labor in previously unaffected industries might be expected to lower wages in those industries. The anti-discrimination provisions might also reduce output in industries subject to those provisions and shift labor and capital toward unaffected industries. A shift which increased the ratio of labor to capital in the previously unaffected industries might further depress the wages in those industries. ${ }^{92}$ The antidiscrimination requirements might also affect employee savings, which in turn might affect business investment, household con-

Sheinkman, Vice President of Amalgamated Clothing Workers of America) ("The retirement program, while concededly an important part of the negotiated economic package, is only one part, and not the only part. If the Congress, passes this, or similar proposed legislation it must affect the ability of the Amalgamated to bargain concerning these other bargaining objectives in the context of all of the economic factors. . . The problem then arises whether the benefit sought to be obtained by such legislation is worth the ultimate cost ...."). Union opposition to legislative interference in the wage mix is not absolute and does not necessarily imply that interference in the wage mix of non-unionized employees is undesirable. For example, unions may possess important information on retirement income which non-unionized employees lack. Interference in union-bargained agreements may therefore be unnecessary.

91 Generally speaking, the perceived welfare loss introduced by the anti-discrimination requirements might be expected to act as a partial factor tax, such as a tax on corporate income. The analytic framework with which the incidence of a partial factor tax might be determined is discussed in Boadway, Public Sector Economics at 349-412 (cited in note 83); Atkinson and Stiglitz, Lectures on Public Economics at 160-226 (cited in note 88).

${ }^{92}$ Conversely, a shift of resources which reduced the ratio of labor to capital in previously unaffected industries would tend to increase wage rates in those industries. This result might obtain if the affected industry were more capital intensive than the unaffected industry. See Boadway, Public Sector Economics at 364-68 (cited in note 88). 
sumption, employment, and wages.

Consideration of these and other factors suggests that the effect of the anti-discrimination provisions will be less determinate than predicted by the partial equilibrium model. However, there is no reason to believe that a more complex analysis would transform the decline in perceived employee welfare predicted above to an increase in welfare. In the absence of a satisfactory general equilibrium model and analysis, it seems sensible to base policy on the first-order effects and qualitative estimates of other effects. ${ }^{93}$

\section{Employee Welfare, Paternalism and Forced Savings}

Under the model set forth immediately above, employees and employers are assumed to act in their own self-interest and to arrive at the most efficient and valuable mix of cash compensation and pension benefits. The anti-discrimination provisions change that mix, and, in effect, require employees to purchase additional retirement benefits. Under most plausible assumptions, the interference in the compensation mix reduces the value of the wage package to the employee and increases labor costs to the employer.

The conclusions reached in the model would not hold if employees were thought incapable of perceiving or acting in their selfinterest. In such cases, a requirement that rank-and-file employees purchase additional pension benefits might produce an increase in employee welfare, through a paternalistic override of employee decision making.

A paternalistic basis for the anti-discrimination requirements is suggested by the few scholars who have written on the requirements, ${ }^{94}$ and by a number of individuals who have testified before Congress on the requirements; ${ }^{95}$ and some scholars who have developed theories of paternalism support forced purchase of retire-

93 A number of well-respected general equilibrium models now exist. The examination of the effects of the anti-discrimination requirements through one of those models is a primary recommendation of this article.

See Wolk, 70 Va.L.Rev. at 466 (cited in note 73); Altman, 42 Tax L.Rev. at 470 (cited in note 27); Graetz, 135 U.Pa.L.Rev. at 856 (cited in note 6); Halperin, Tax Policy and Retirement Income at 161 (cited in note 27).

95 See, for example, General Tax Reform, Panel Discussions before the House Committee on Ways and Means, 93rd Cong., 1st Sess. 1122 (1973)("Panel Discussions")(statement of Professor Daniel Halperin); Id. at 1139 (statement of Frank Cummings); Retirement Income Security Act, 1972, Hearings on S.3598 before the Subcommittee on Labor of the Senate Committee on Labor and Public Welfare, 92nd Cong., 2d Sess. 202 (1972) (statement of Professor Dan M. McGill). Paternalistic considerations were not articulated in the 1937 hearings on tax evasion or the 1942 legislative debates. 
ment annuities. ${ }^{96}$ However, the arguments for and against paternalism in this area have not been fully developed. ${ }^{97}$

This section will examine distortions in decision making which may prevent employees from acting in their long-term interest and justify forced purchase of retirement benefits. ${ }^{88}$ This section will also examine the argument that the public burden posed by indigent elderly justifies forced purchase of retirement benefits.

The last part of this section will assume, arguendo, that forced savings is desirable and will examine the use of the anti-discrimi-

${ }^{98}$ See Gerald Dworkin, Paternalism, in Rolf Sartorius, ed., Paternalism 20 (1983); Joel Feinberg, Harm to Self 18 (1986); John Kleinig, Paternalism 165-68 (1984).

${ }_{97}$ Tax scholars who write on the anti-discrimination provisions generally assume a paternalistic basis for the provisions but direct their attention to other issues, such as the gaps in participation and vesting.

Moral philosophers who support forced purchase of retirement annuities often base their support on non-paternalistic grounds. Professors Feinberg and Kleinig, for example, both discuss the issue of forced retirement saving in the context of the social security system. Feinberg believes the universal coverage of social security is necessary because of market failure: in a non-compulsory system, for-profit companies would not be able to offer adequate retirement benefits. Feinberg, Harm to Self at 18 (cited in note 96). Kleinig believes that in a non-compulsory system for-profit companies would offer retirement annuities to the wealthy but not to the poor. Kleinig, Paternalism at 165-68 (cited in note 96). To a lesser extent, Kleinig believes that social security is necessary to avoid state support of the elderly. Id. at 165-66.

The merit of Feinberg's and Kleinig's core non-paternalistic argument in favor of social security-that social security maximizes welfare because of the inability of the market to offer non-redistributive annuities-is thoughtfully discussed in R. Glenn Hubbard and Kenneth L. Judd, Social Security and Individual Welfare: Precautionary Saving, Borrowing Constraints, and the Payroll Tax, 77 Am.Econ.Rev. 630 (1987). The argument would not justify forced saving through private pensions, since private pensions are a form of "market" pensions which, under the terms of the argument, are non-optimal.

${ }^{98}$ The assumption that paternalistic intervention must be predicated upon distortions in decision making is consistent with a prominent strand of moral theory. Joel Feinberg has recently proposed a theory of "soft" or "weak" paternalism which justifies intervention in self-regarding conduct which, because of distortions caused by ignorance, compulsion, or the like, may properly be regarded as non-voluntary. Feinberg, Harm to Self at 18 (cited in note 96). Feinberg opposes "hard" or "strong" paternalistic theories which would justify intervention in conduct which is voluntary or the product of genuine consent. Id. His moral theory is built upon, and similar to, theories set forth by other scholars. See Dworkin, Paternalism at 19 (cited in note 96); Kleinig, Paternalism (cited in note 96).

The task of distinguishing between actions premised upon genuine consent (which must be respected) and actions driven by delusive belief (which must be overturned) constitutes a primary difficulty in mapping Feinberg's theory onto real world situations. For example, it is not clear whether interference with harmful actions dictated by character traits such as impulsiveness or neurosis constitutes a form of hard or soft paternalism. See Feinberg, Harm to Self at 150-53 (cited in note 96).

This article will not attempt to provide a unified theory of legal paternalism or to examine the link between "voluntary" behavior and welfare-maximizing behavior. Instead, this work will examine the set of empirical assumptions which-under differing views as to the definition of, and weight accorded to, welfare and personal autonomy-might justify a regimen of forced retirement savings. 
nation provisions to effect that savings.

\section{A. Arguments for Forced Purchase of Retirement Benefits}

Mistakes of Fact, Incapacity and Incompetence. Mistaken assumptions as to issues which are subordinate or unrelated to an individual's central belief structure provide a relatively untroublesome basis on which to override individual choice. Interference with action premised upon a factual error-such as the ingestion of poison in the belief that it is medicine-may be assumed to improve the actor's welfare and not to impinge upon central values of personal autonomy.

Effective retirement planning is extraordinarily complex and might well be distorted through factual mistake. The amount of current saving required to support a desired life style upon retirement is dependent upon future income, health and life expectancy, short-term and long-term inflation, and the risk-adjusted rate of return on alternative investments. ${ }^{99}$ Relatively minor errors can significantly affect the financial resources available upon retirement. For example, an individual who makes an investment of $\$ 10,000$ on the assumption that inflation will run $4 \%$ per year and that the investment will compound at a rate of $7 \%$ per year will expect a present value sum of approximately $\$ 27,000$ at the end of thirty-five years. ${ }^{100}$ If inflation turns out to compound at an annual rate of $5 \%$, and the investment compounds at $6 \%$, the present value sum available at the end of thirty-five years will be only about $\$ 14,000$-a little more than one-half the expected amount. ${ }^{101}$ Even if erroneous factual assumptions lead to overpurchase of retirement benefits as often as they lead to underpurchase, the consequences to the individual of underpurchase may be more severe.

The mistake-grounded justification for forced purchase of retirement benefits is quite appealing. In opposition to this form of justification, however, it can be argued that employees may be able to avoid miscalculation through the use of for-profit advisors, vol-

99 The facts needed to intelligently plan for retirement are discussed in Altman, 42 Tax L.Rev. at 248 (cited in note 27).

${ }^{100}$ The formula for computing the future sum of a single payment is $f s=R *(1+i)^{n}$, where $R$ is the payment, $i$ is the annual nominal interest rate and $n$ is the number of periods. The formula for calculating the present value of a future sum discounted back by the inflation rate is $p v=f s /(1+I)^{n}$, where fs is the future sum, $I$ is the inflation rate, and $n$ is the number of periods. In thirty-five years, 10,000 compounded at $7 \%$ yields a future sum of approximately $\$ 106,766$. The present value of that sum at a $4 \%$ inflation rate is $\$ 27,056$.

${ }_{101}$ The future sum of $\$ 10,000$ compounded for thirty-five years at $6 \%$ is approximately $\$ 76,861$. The present value of that sum at a $5 \%$ inflation rate is approximately $\$ 13,934$. 
untary contributions to employer-managed pension plans, or the purchase of products, such as deferred annuities, offered by regulated financial institutions. Also, depending on the information costs involved, underpurchase due to factual mistake might be less intrusively handled through government-supplied information, rather than through forced purchase. ${ }^{\mathbf{1 0 2}}$

The case for intervention in the compensation mix alternatively might be based on a different kind of mistake: an erroneous belief as to the importance of income upon retirement. An employee in her early working years may believe that a high retirement standard of living will bring her little enjoyment. Upon retirement, that same employee may find additional income for consumption and bequests extremely desirable. Since the erroneous assumption as to the value of future income may reflect a complicated and deeply held set of beliefs as to life-prospects, it is unlikely to be dislodged by the less intrusive alternative of government-supplied information. A mandatory increase in retirement saving may increase welfare and, in some sense, cohere with the employee's true preference structure.

Even if retirement planning is not subject to factual mistakes, the inability of employees effectively to make use of factual information may justify forced purchase of retirement annuities. Retirement planning requires a facility with numbers, and the ability to understand, if not calculate, compound rates of return, amortization schedules, and the present value of a future sum. Retirement planning also requires an ability to deal with the uncertainty of investment and health projections. An inability to correctly process factual assumptions may prevent an employee from reaching a desired level of retirement income. For example, employees may be unable to discount promised future sums for inflation. At plausible interest rates, an annual $\$ 2,000$ individual retirement account contribution may produce a fund of nearly one million dollars after forty years ${ }^{103}$ - a fact often noted by financial institutions. The present value of that sum, however, may be less than one hundred thousand dollars. ${ }^{104}$

Another competence-based justification for forced retirement

${ }^{102}$ Retirement planning-related information costs are discussed in Lawrence $\mathrm{H}$. Thompson, The Social Security Reform Debate, 21 J.Econ.Lit. 1425 (1983).

${ }^{103}$ At an interest rate of $10.5 \%$, a $\$ 2,000$ annual contribution will yield approximately $\$ 1,014,000$ at the end of 40 years.

104 At a discount or inflation rate of $6 \%$, the present value of $\$ 1,014,000$ in 40 years is approximately $\$ 99,000$. 
saving might be based on a psychodynamic model of employee decision making. Retirement planning requires the contemplation of one's own incapacity and death. Such contemplation is apt to produce anxiety; employees might attempt to reduce this anxiety through symbolic, rather than effective action. ${ }^{105}$ Death-related anxiety might be responsible for the myopic behavior often attributed to young employees and occasionally cited as justification for a regimen of forced saving. ${ }^{106}$ Evidence of the distorting effect of death anxiety is found in accounts of estate planners and social workers. ${ }^{107}$

It may be possible to structure the retirement planning decision so as to minimize the effects of both cognitive and psychoanalytic-based distortions. The relevance of annuities and present value analysis might be explained through employer or government-provided material and mandatory conferences with employer or government personnel. Such material or conferences might be structured so as to force the employee to confront the prospect of retirement. Such a structure, however, might prove so expensive that forced retirement saving becomes a more attractive alternative.

Overall, there is very little useful knowledge, one way or another, as to whether various disabilities or erroneous factual assumptions cause individuals to undersave. ${ }^{108}$ However, the lifetime savings and consumption decisions of individuals have been the subject of a number of studies. ${ }^{109}$ One recent study indicates that

${ }^{105}$ The existence and distorting effect of death-anxiety forms the primary focus of Ernst Becker's book, The Denial of Death (1973). More traditional psychoanalytic theory also acknowledges death anxiety, though it is often treated as a secondary variant of castration anxiety. See Martin L. Levine, Age Discrimination and the Abolishment of Mandatory Retirement (1987).

${ }^{106}$ See Altman, 42 Tax L.Rev. at 472-73 (cited in note 27); Thompson, 21 J.Econ.Lit. at 1141 (cited in note 102); Labor Panel Discussions at 1122, 1139 (statements of Cummings and McGill)(cited in note 95).

${ }^{107}$ See Thomas L. Shaffer, The Planning and Drafting of Wills and Trusts 13-19 (1979) (role of the estate planner in helping client deal with issues surrounding death); Lou Harris and Associates Inc., Retirement and Income at xi, 23, 24 (cited in note 75).

${ }^{108}$ The issue is discussed briefly in Peter A. Diamond, A Framework for Social Security Analysis, 8 J.Pub.Econ. 275, 281 (1977).

${ }^{108}$ See, for example, Alan S. Blinder, Roger H. Gordon, and Donald E. Wise, Social Security, Bequests and the Life Cycle Theory of Saving: Cross Sectional Tests in Franco Modigliani and Richard Hemming, eds., The Determinants of National Saving and Wealth 89 (1983); Daniel S. Hamermesh, Consumption During Retirement: The Missing Link in the Life Cycle, 66 Rev.Econ. \& Stat. 1 (1984); M.A. King and L-D.L. Dicks-Mireaux, Asset Holdings and the Life-Cycle, 92 The Econ.J. 247 (1982); Thad W. Mirer, The Wealth-Age Relation Among the Aged, 69 Am.Econ.Rev. 435 (1979); Lawrence J. Kotlikoff, Avia Spivak and Laurence H. Summers, The Adequacy of Savings, 72 Am.Econ.Rev. 1056 (1982); Paul 
post-retirement consumption is approximately equal to average lifetime consumption. ${ }^{110}$ Other studies suggest that financial wealth remains relatively stable after retirement, even among individuals of modest wealth and even in the absence of a strong bequest motive. ${ }^{111}$ These and other studies have led some economists to conclude that employees do not undersave. ${ }^{112}$

On the other hand, at least one study suggests the presence of undersaving, ${ }^{113}$ and the results of the more optimistic studies are subject to various interpretations. For example, while post-retirement consumption may be equal to average lifetime consumption, it is lower than the consumption enjoyed by individuals immediately prior to retirement. ${ }^{114}$ Moreover, post-retirement consumption is reported to be significantly below average lifetime consumption for the poorly educated.115 Additionally, the retention of wealth may be necessary to meet the contingent costs of catastrophic illness or unexpected longevity and may offer no useful information as to the adequacy of pre-retirement saving. The optimistic conclusions of many of the studies are to some degree inconsistent with the less quantitative analysis of sociologists and social workers. ${ }^{116}$ More generally, it is unclear whether it is possible to

N. Courant, Edward M. Gramlich, and John P. Laitner, A Dynamic Microeconomic Estimate of the Life-Cycle Model, in Henry J. Aaron and Gary Burtless, eds., Retirement and Economic Behavior 279 (1984).

110 Kotlikoff, 72 Am.Econ.Rev. 1056 (cited in note 109). The study used longitudinal data collected by the Social Security Administration to compare the consumption patterns of individuals with the patterns which would have been produced had the individuals used wealth to purchase lifetime annuities. The "healthy" results reflect the present social security and pension regimen. It is possible that the absence of forced private pension saving would lead to a decline in post-consumption income. Id. at 1068. See also Courant, Gramlich, and Laitner, A Dynamic Microeconomic Estimate of the Life-Cycle Model (cited in note 109).

${ }^{111}$ See, for example, Blinder, Gordon, and Wise, Social Security, Bequests and the Life Cycle Theory of Society (cited in note 109); Mirer, 69 Am.Econ.Rev. at 442 (cited in note 109).

112 See Kotlikoff, 72 Am.Econ.Rev. at 1068 (cited in note 109). See also Stephen Johnson, Lawrence J. Kotlikoff, and William Samuelson, Can People Compute? An Experimental Test of the Life Cycle Consumption Model, National Bureau of Economic Research, Working Paper No. 2183 (1987) (experimental evidence, together with review of econometric evidence suggest that individuals may oversave for retirement).

${ }^{113}$ Blinder, Gordon, and Wise, Social Security, Bequests and the Life Cycle Theory (cited in note 109).

114 See Hamermesh, 66 Rev.Econ. \& Stat. at 4 (cited in note 109).

115 Kotlikoff, 72 Am.Econ.Rev. at 1067 (cited in note 109).

116 Sociologists and political scientists generally draw a much darker picture of the economic status of the aged. See, for example, Robert $H$. Binstock, Reframing the Agenda of Policies on Aging, in Meredith Minkler and Carroll L. Estes, eds., Readings in the Political Economy of Aging 157-58 (1984) ("A relatively small number of aged are very well-off; many are moderately comfortable; many are extraordinarily poor"). 
impute rationality or irrationality to savings behavior simply by observing the statistical dimensions of that behavior.

Some insight into employee decision making may also be gained by comparing the pension levels of union and non-union employees. Because the anti-discrimination requirements impose a minimum but not a maximum level of rank-and-file pension benefits, one might expect that non-union employees, who are covered by the anti-discrimination requirements, would receive larger pensions than union employees, who are exempt or "unprotected" by the requirements. In fact, when all other known variables are held constant, pension benefits for pensioned union employees are as high or higher than pension benefits for pensioned non-union employees. ${ }^{117}$ Moreover, union employees are much more likely to receive pensions. ${ }^{118}$

The difference in pension levels may reflect the greater information available to union negotiators and members. Unions may provide employees with credible information on the value of pension benefits, and employees may be more apt to disclose preferences to union negotiators than to management. If this is true, government intervention in the compensation mix may be supported on the ground that it provides non-union employees with benefits selected by better informed, but otherwise similar, union employees.

The differences in pension levels may be attributable to other factors, as well. Union-negotiated compensation packages may reflect the desires of the median, or perhaps the long-term employee, ${ }^{119}$ whereas, as noted earlier, non-union compensation packages reflect the desires of marginal employees. Union leaders also may use their delegated power to act paternalistically toward union members. These explanations do not isolate a source of distorted decision making, but they do suggest that a minimum level of pension benefits may improve the welfare of rank-and-file employees.

Reduced governmental support. While most typically justified in terms of employee welfare, a regimen of forced saving has also been justified as a means of reducing governmental expendi-

${ }^{117}$ Laurence J. Kotlikoff and Daniel E. Smith, Pensions in the American Economy (1983); Richard B. Freeman, Unions, Pensions, and Union Pension Funds, in Wise, ed., Pensions, Labor, and Individual Choice at 89 (cited in note 7).

118 See authorities cited in note 117.

119 See Freeman, Union Pension Funds (cited in note 117). 
tures. ${ }^{120}$ The government may be reasonably expected to provide some sort of support for the indigent elderly; forced savings of individuals in their working years might plausibly reduce the amount of support required after retirement. ${ }^{121}$ The labor supply model described earlier focuses only on the individual welfare of rank-andfile workers; arguments for reduced government spending highlight the separate issue of societal welfare.

The strength of this justification depends primarily on the importance placed on fiscal economy, and the feasibility and desirability of imposing a savings requirement on those low-paid members of the rank-and-file who are most apt to comprise the elderly poor. A large portion of the income earned by low-paid employees goes to purchase necessities and near-necessities. Forced purchase of retirement benefits might deprive such employees of funds currently needed to raise families or otherwise maintain a barely adequate lifestyle.

Summing up the case for forced savings. As has been shown, proposals for or against forced retirement saving raise nearly unresolvable issues. While there are many good arguments in favor of forced saving, none of those arguments is without difficulty. Perhaps the most that can be said is that the cumulative weight of the arguments, considered in light of the misery faced by the elderly poor, might plausibly support a regimen of forced saving. ${ }^{122}$

\section{B. Use of the Anti-Discrimination Provisions to Achieve Forced Savings}

A belief that some form of forced saving is necessary would not in itself justify the anti-discrimination provisions. Instead, the anti-discrimination requirements will be desirable only if they are seen as an efficacious way of bringing about such saving. This is not the case.

${ }^{120}$ See Labor Subcommittee Hearings at 193 (statement of McGill)(cited in note 95); Ippolito, Pensions and Economics at 33, 38 (cited in note 8). A number of commentators have also justified social security on the grounds that it reduces governmental support. See, for example, Richard Musgrave, The Role of Social Insurance in an Overall Program for Social Welfare, in William G. Bowen, et al., eds., The American System of Social Insurance 23, 26 (1968); Thompson, 21 J.Econ.Lit. at 1440-41 (cited in note 102). That position, of course, implicitly assumes that social security is more appropriately viewed as a form of forced saving than as a governmental transfer payment.

121 Under some sets of factual assumptions and moral theories, forced saving might be necessary to offset the undesirable incentives created by support payments. Welfare for the aged encourages employees to increase current consumption and rely on the fisc for retirement support.

122 A similar view is expressed in Thompson, 21 J.Econ.Lit. at 1442 (cited in note 102). 
The anti-discrimination requirements affect employees in an essentially arbitrary manner. The level of retirement savings produced by the provisions depends critically on the size, interests and bargaining power of each class of employees, and on the various statutory definitions, requirements, and exceptions. For example, since tax-favored pension benefits are more valuable to highly compensated employees, firms with a large proportion of highly compensated employees are apt to build the compensation mix desired by those employees, and to offer a high level of pension benefits. Other companies are apt to fashion a compensation mix which enables them to more effectively compete for rank-and-file workers.

The peculiar effect of anti-discrimination provisions on retirement benefits may be illustrated by considering a three-firm world with a workforce comprised of a set of identically situated highly compensated employees and a separate set of identically situated rank-and-file employees. All highly compensated employees desire pension benefits equal to $8 \%$ of their compensation; all rank-andfile employees desire pension benefits equal to $2 \%$ of their compensation. As depicted in Table 1, the ratio of pension benefits to compensation depends solely on the ratio of highly compensated to rank-and-file employees. Firm 1 has many highly compensated employees and few rank-and-file employees. Acting on the profit-maximizing behavior described in the labor supply model depicted earlier, the firm selects a compensation mix in which pension benefits comprise approximately $8 \%$ of compensation. Firm 3, on the other hand, has many rank-and-file workers and few highly compensated employees. It thus fashions the benefits package desired close to that by the former group. Firm 2 falls somewhere in between.

In the real world, the impact of the anti-discrimination requirements would depend not only on the interests and numbers of various classes of workers, but on the responsiveness of each class to changes in the wage rate. In one market, a decrease in the perceived value of the compensation package to rank-and-file workers may sharply reduce the labor supply and thereby increase labor costs. The compensation package in this market may favor the interests of rank-and-file workers. In another labor market, a reduction in the perceived value of the compensation package to the rank-and-file workers may not seriously affect the labor supply or wages, and the employer may design the compensation package to suit the interests of highly compensated employees.

In the real world, too, the desired compensation mix may sometimes be unrelated to income level. And in some cases, highly 
compensated managers may set the wage mix to maximize their own interests rather than the interests of their employees. ${ }^{123}$ The effect of these and other factors is summarized in Table 2.

\section{TABLE 1}

Responsiveness of compensation mix to relative proportion of highly compensated and rank-and-file employees (Figures based on hypothetical supply and demand elasticities).

\section{Highly Compensated Employees \\ \# \% salary desired in form of pension benefits}

$\begin{array}{cl}\begin{array}{c}\text { Rank \& File } \\ \text { Employees }\end{array} & \\ \# & \begin{array}{l}\% \text { salary desired } \\ \text { in form of } \\ \text { pension benefits }\end{array} \\ & \end{array}$

Firm $1 \quad 99 \quad 8 \%$

Firm $2 \quad 50 \quad 8 \%$

Firm $3 \quad 1 \quad 8 \%$

$\begin{array}{rl}1 & 2 \% \\ 50 & 2 \% \\ 99 & 2 \%\end{array}$

$2 \%$

Selected \%

\section{TABLE 2}

Factor

Impact on ratio of pension benefits to salary

Large percentage of highly compensated employees

Large percentage of rank \& file employees

Relative responsiveness of highly compensated employees to changes in perceived compensation

Relative responsiveness of rank-and-file employees to changes in perceived compensation

"Capture" of enterprise by highly compensated managers
Increases pension levels to amounts desired by highly compensated employees

Decreases pension levels to amounts desired by rank \& file employees

High responsiveness raises pension levels to amounts desired by highly compensated employees

High responsiveness decreases levels to amounts desired by rank-and-file employees

May increase pension levels to by amounts desired by highly compensated employees

By now it should be obvious that the retirement savings produced by the anti-discrimination provisions bears no relation to the amount of savings envisioned by the various rationales for forced saving. A regimen based on considerations of fiscal thrift, for example, might impose a level of savings designed to minimize

${ }^{123}$ Such a state of affairs might occur if, because of agency problems, the managers effectively "capture" partial control of an enterprise and find an otherwise unjustified increase in benefit ratios a useful means by which to extract profit. 
welfare costs. Guidelines might be developed on the ability to support oneself upon retirement, in much the same way that the ability to support oneself is evaluated for purposes of immigration. By hypothesis, rank-and-file employees in firms $1-3$ in Table 1 are equally capable or incapable of self-support after retirement. Yet the amount of retirement savings ranges from $2 \%$ to $8 \%$ of compensation-a $400 \%$ spread. There is no reason to think that the other factors described above would produce a more uniform compensation mix or a compensation mix related in any way to the goal of reduced support costs.

Examination of the other justifications for forced saving also show a lack of relationship between goal and result. For example, it is inconceivable that the undersaving caused by the various forms of mistake would be related in any way to the ratio of highly compensated to rank-and-file employees, the relative responsiveness of each class of employees to changes in the wage rate, the possibility that the employer will be "captured" by highly compensated employees, or any of the other determinants of the compensation mix under the anti-discrimination rules.

The arbitrary impact of the anti-discrimination provisions on affected employees argues strongly against the use of such provisions as a way in which to increase retirement savings. But the anti-discrimination provisions suffer from other drawbacks as well. The anti-discrimination requirements cover less than one-half of the labor force. Employees whose employers do not offer pensions plans, who belong to a union, or who may be excluded from coverage under the participation or vesting rules are not protected by the anti-discrimination requirements. Statistically, the excluded employees are for the most part the poorest employees-the very group presumably most in need of additional retirement benefits-and this fact is not likely to change. In a workforce comprised of low-paid employees, the net advantages of pension savings may not be great enough to justify the administrative expense of maintaining a plan. Moreover, low-paid workers are far more likely than highly compensated employees to experience periods of job instability, and thus face exclusion from pension coverage under the participation and vesting requirements. ${ }^{124}$

The exclusion of low-paid workers from company-sponsored plans might be addressed through tighter participation and coverage rules-a process advocated by many legal scholars and policy 20).

324 President's Commission on Pension Policy, Coming of Age at 27-33 (cited in note 
makers. ${ }^{125}$ Recent legislation represents a step in this direction. ${ }^{126}$ However, within the present framework there is no apparent method of increasing the number of company-sponsored plans.

\section{Alternative Means of Forced Savings}

The analysis thus far has suggested that the anti-discrimination provisions do not seem a useful means by which to force retirement saving. How, then, might such saving be assured? There is no easy answer to the question, but two approaches seem somewhat promising. First, Congress might adopt a uniform mandatory level of pension saving. Such saving could be carried out through existing employer-provided plans. Employees whose employers do not have qualified plans could contract out for such plans with regulated investment companies; as a last resort, the government might manage a plan. Plan coverage would be universal and benefits would vest immediately.

Mandatory pension coverage was recommended a decade ago by a commission on pension policy appointed by President Carter. ${ }^{127}$ The proposal was well-received by many scholars ${ }^{128}$ but did not produce political change, perhaps because of the uncertainty over administrative costs. ${ }^{129}$ In the last ten years, however, the financial services sector has dramatically expanded. The number of defined contribution pension plans, under which retiring employees receive the sum of employer contributions and investment gains and losses on those contributions, has also increased. Today, regulated investment companies, such as banks, insurers, and industry-wide pensions, offer a wide variety of reasonable cost pension investments for employees with defined contribution plans. Participants in such plans currently choose which investment company and fund shall manage their vested contributions.

Because of these changes, a mandatory defined contribution plan now seems administratively feasible, though the short-term

${ }^{125}$ See President's Commission on Pension Policy, Coming of Age (cited in note 20); Halperin, Tax Policy and Retirement Income (cited in note 27); Graetz, 135 U.Pa.L.Rev. at 851 (cited in note 6); Altman, 42 Tax L.Rev. 433 (cited in note 27).

${ }_{128}$ See Tax Reform Act of 1986 (cited in note 66).

${ }^{127}$ See generally, President's Commission on Pension Policy, Coming of Age (cited in note 22).

${ }^{128}$ See Graetz, 135 U.Pa.L.Rev. at 907 (mandatory pension coverage preferable to present regiman)(cited in note 7); Halperin, Tax Policy and Retirement Income at 194 (cited in note 27); Wolk, 70 Va.L.Rev. 419 (cited in note 30 ).

129 High transaction costs are cited by Professor Altman as one reason for favoring the present regiman over a mandatory pension. Altman, 42 Tax L.Rev. at 503 (cited in note 27). 
and mid-term political prospects for such a change seem slim. The main novelty in such a plan would be to require a new and large set of employees to make the same kind of choices, and participate in the same kinds of plans, as millions of existing employees. A mandatory defined benefit plan, which is favored by many legal scholars because benefits are fixed and do not depend on the investment experience of contributions, still poses considerable administrative burdens.

Universal pension coverage is required by Finland and Switzerland; many other European nations have adopted a modified form of universal pension coverage. ${ }^{130}$ While the European pension system is not without problems and does not present a direct analog to the American system, it strongly suggests that a system of universal pension coverage would be administratively feasible. ${ }^{131}$

An alternative approach to retirement security would be to provide pension coverage through the tax-transfer system. Payments might be funded out of general revenues and distributed on the basis of need. A tax-transfer regimen would not be a form of forced saving and would be unacceptable to those who support forced saving as a mechanism to reduce government transfer payments. However, a tax-transfer regimen would accomplish the primary objective of forced saving: improving the welfare of the elderly poor.

Finally, retirement security might be achieved through an increase in social security payments and contributions. Social security bears many of the characteristics of a tax-transfer system: payments are made by a current generation of workers to a prior generation of workers and are based on a formula subject to periodic legislative revisions. ${ }^{132}$ On the other hand, because benefits are loosely linked to contributions, social security bears some of the characteristics of a required private pension. ${ }^{133}$ The coverage of social security is nearly universal. ${ }^{134}$

${ }^{130}$ In France and Sweden, pensions are negotiated through nationwide bargaining agreements and coverage rates are extremely high. The European system of public and private pension coverage is described in President's Commission on Pension Policy, An International Comparison of Pension Systems (1980).

${ }^{131}$ One fundamental difference between American and European private pensions is that, as of 1980 , the latter are not required to be fully funded. Id. at 47 .

${ }^{232}$ The social security system is summarized in Robert J. Myers, Social Security 19-177 (1975); a capsule description is found in George E. Rejda, Social Insurance and Economic Security 19-28 (2d ed. 1984).

${ }^{133}$ See Thompson, 21 J.Econ.Lit. 1425 (cited in note 102).

134 The only significant exceptions to universal employee social security coverage are some state employees, governmental employees who receive benefits under the Civil Service 
The choice among the three methods of insuring retirement income would depend upon administrative costs and conceptions of distributive justice. A tax-transfer regimen based on need would be highly progressive. Social security funds are collected in a regressive fashion and distributed in a highly progressive fashion; the net effect of an increase in social security would probably be somewhat progressive. ${ }^{135}$

The amount of universal coverage, retirement-related taxtransfer payments, or increase in the social security system would depend on the paternalistic or fiscal rationales which are thought to justify government action, and would ideally take into account the effect of required savings on economic behavior of affected employees. ${ }^{136}$ Such a determination would raise terribly difficult normative and factual issues. However, the present regimen is so irrational that even an uneducated legislative judgment call is apt to be an improvement. It may not be clear how much retirement income should be augmented by forced saving or transfer payments, but it seems clear that the amount of forced saving or retirement income should not depend on the existence of an employer-provided pension plan, or factors such as the relative proportions of highly compensated and rank-and-file employees. ${ }^{137}$

Retirement System, and railroad workers who receive benefits under the Railroad Retirement Act. See President's Commission on Pension Policy, Coming of Age at 12 (cited in note 20) (90\% coverage ratio for social security); Joseph A. Pechman, Henry J. Aaron, Michael K. Taussig, Social Security: Perspectives for Reform 37 (1968) (explanation of coverage growth and rules).

${ }^{135}$ Social security collections are regressive because, as noted above, no tax is collected on incomes above $\$ 45,000$. Social security distributions are progressive because the ratio of distributions to wages falls as wages rise. The social security collection-distribution system is described in Myers, Social Security at 21-166 (cited in note 129). A more lucid, though in some sense dated, description is found in Pechman, Perspectives on Reform at 78 (cited in note 131). See also Michael D. Hurd and John B. Shoven, The Distributional Impact of Social Security in Wise, ed., Pensions, Labor, and Individual Choice 193 (1985) (study of past and future impact of social security by cohort group).

${ }^{136}$ One likely effect of any required saving regimen would be to reduce the amount of private non-required saving. Mandatory pension contributions or increased social security contributions must be sufficient to offset this reduction if they are to have any effect. One economist has ventured a "reasonable conjecture" that workers reduce saving by 65 cents for each dollar of saving through pensions plans. Munnell, Economics of Private Pensions at 77 (cited in note 8). In the analogous area of social security, economists have been unable to reach a consensus as to the degree to which required saving is offset by a decline in private savings. See generally, Henry J. Aaron, Economic Effects of Social Security 51-52 (1982); Thompson, 21 J.Econ.Lit. at 1445 (cited in note 102). But see Sheldon Danziger, Robert Haveman and Robert Plotnick, How Income Transfer Programs Affect Work, Savings, and the Income Distribution: A Critical Review, 19 J.Econ.Lit. 975, 1006 (1981) (social security and other transfer programs cause $0-20 \%$ decline in private saving).

${ }^{137}$ There would, however, appear to be at least one situation where a more considered 


\section{Justification on Equality-Related Grounds}

The rhetoric accompanying the enactment of the anti-discrimination provisions emphasized the egalitarian need for, and nature of, the provisions. Indeed, the very term "anti-discrimination" suggests an equality-based justification. However, neither Congress nor any commentator has articulated a concept of equality which might underlay the provisions. And on close examination it seems unlikely that the anti-discrimination requirements would be supported by any plausible equality ideal.

A central argument of this article is that the anti-discrimination requirements lead to both the advantage of increased pension benefits and the disadvantage of reduced cash wages. The requirements thus change, rather than add to, the compensation mix. If employees are thought to maximize their own welfare, a compensation mix with higher pension benefits mandated by the anti-discrimination rules will be less valuable than a mix produced by employee-employer bargaining. The anti-discrimination requirements would therefore reduce welfare. It is unlikely that any conception of equality based even in part on individual well-being would require a decline in welfare of the poorer of two classes of workers. ${ }^{138}$

The argument for forced saving rejects the belief that the market produces an optimum compensation mix. However, the argument acknowledges that the anti-discrimination requirements produce both advantages and disadvantages and thus calls into question any attempt to draw a straightforward link between mandated benefits and equality goals.

Even if the reduction in cash salary is ignored so that the antidiscrimination requirements unambiguously increase welfare, equality justifications seem inconsistent with the inter-firm inequalities produced by the requirements. As noted earlier, the effect of the requirements will vary with the proportion of rank-and-file and highly compensated employees, and with the supply and demand curve of and for those employees. Employees in different firms will receive different benefits.

In some circumstances, of course, equality may be most appropriately measured within the firm. For example, a firm's decision

form of saving would be undesirable. If, on reflection, forced saving itself seems unjustified, the more systematic regimen advocated herein might actually reduce welfare. A mandatory universal pension or social security tax would affect virtually all employees. The more encompassing scope would accentuate the costs of an erroneous decision as to the desirability of forced saving.

${ }^{138}$ See text accompanying notes 94-137. 
to reserve specific washrooms for executives may seem undesirable regardless of whether the lesser washrooms provided to other employees are as good as the washrooms provided to all employees at other firms. However, most conceptions of equality built around ideals such as welfare, desert, or resources would presumably be as interested in equality of welfare among employees at different firms as equality of welfare among employees at a single firm. The selection of the firm as the relevant community through which to determine benefits seems particularly inappropriate in a society whose workforce is increasingly mobile.

The adoption of proportionate, rather than absolute or other measures of equality also seems to fit uneasily with most plausible conceptions of equality. Welfarist or natural rights conceptions of equality might well require more than proportional equality. For example, a conception of equality as maximization of the welfare or material goods of the least well-off class of individuals would allocate at least as many pension benefits to the rank-and-file employees as to the highly compensated employees. In other areas of the tax law absolute equality is held as the ideal: employers who offer tax-free medical benefits must offer the same medical benefits to all employees. ${ }^{139} \mathrm{~A}$ system which allocated votes or legal rights in proportion to income would strike almost everyone as odd.

Indeed, in at least one important sense, the anti-discrimination provisions do not produce equality so much as mask inequality. Pension benefits are expensive and reduce the amount of cash compensation otherwise available; like most other expensive goods, such benefits would normally be purchased primarily by the wealthy. Favorable tax provisions, which disproportionately benefit high income taxpayers, might be expected to increase, rather than decrease, the disparity in pension coverage.

A system in which the wealthy received pension benefits and the poor did not might highlight the difficult position of the working poor and make many members of society uncomfortable. The anti-discrimination requirements mask the appearance but not the reality of that position by forcing the working poor to purchase pension benefits they do not wish to purchase and may feel they cannot afford. It is as if the government responded to the housing and health problems faced by the working poor by requiring such individuals to spend more of their income on housing and medicine. Such a requirement would be justified, if at all, on pater- 
nalistic rather than equality-related grounds.

\section{Reduction of an Undesirable Tax Benefit}

Today, the rule of proportionate equality is generally thought to raise the benefits of rank-and-file employees. However, an employer might also meet the requirement of proportionality by reducing the benefits of the highly compensated. It was this latter possibility which played a key role in the enactment of the original anti-discrimination provisions. As discussed previously, Congress in 1942 seemed more interested in reducing the perceived overuse of the pension savings provisions by the highly compensated than in expanding pension coverage of rank-and-file.

A reduction in pension benefits might enable the tax law to adhere more closely to widely-held conceptions of tax equity. Under the so-called Haig-Simons tax base, each individual should be subject to tax on the sum of the amount consumed and net accretion to wealth in the taxable year. ${ }^{140}$ The Haig-Simons tax base is supported because it is thought to provide for the apportionment of the tax burden according to individual economic resources. ${ }^{141}$

Contributions to pension plans and interest earned on those contributions are generally thought to comprise an accretion to wealth subject to an annual tax under the Haig-Simons ideal. ${ }^{142}$ This is true even though the amounts may not be withdrawn until retirement. Yet under current law, taxation of this form of wealth accretion is deferred until retirement. The lack of conformity with the Haig-Simons ideal may be thought particularly undesirable be-

${ }^{140}$ See Henry C. Simons, Personal Income Taxation $49-50$ (1938); Robert Murray Haig, The Concept of Income-Economic and Legal Aspects, in Robert Murray Haig, ed., The Federal Income Tax 1, 7 (1921).

141 See Simons, Personal Income Taxation (cited in note 137); Richard Goode, The Individual Income Tax 11 (1976). The Haig-Simons tax base excludes one obvious economic resource: property. This omission is perhaps justified on the grounds that the Haig-Simons tax base includes accretion to wealth which produces property and because apportioning the tax according to property would encourage consumption over savings.

${ }_{142}$ See Emil M. Sunley, Jr., Employee Benefits and Transfer Payments in Joseph A. Pechman, ed., Comprehensive Income Taxation 80 (1977). Professor Strnad has argued that the Haig-Simons definition of income should be read to incorporate the concept of present value. See Jeff Strnad, Taxation of Income from Capital: A Theoretical Reappraisal, 37 Stan.L.Rev. 1023 (1985); Jeff Strnad, Tax Timing and the Haig-Simons Ideal: A Rejoinder to Professor Popkin, 62 Ind.L.Rev. 73 (1986-87). Under such an interpretation, the income tax is identical to one form of the consumption tax described below, and the treatment of pension plan is consistent with the tax base ideal. Strnad's interpretation, however, has been challenged by other commentators. See Louis Kaplow and Alvin C. Warren, Jr., An Income Tax by Any Other Name-A Reply to Professor Strnad, 38 Stan.L.Rev. 399 (1985). 
cause, as noted earlier, the pension savings provisions disproportionately benefit the highly compensated. A reduction in the contributions or benefits of highly compensated employees would reduce the deviation from the Haig-Simons ideal.

A reduction in contributions or benefits would also decrease the disparity between individuals who receive pensions and those of equal wealth who must save for retirement though interest-bearing accounts or notes. The former, as noted, may defer tax on accretion to wealth; the latter may not. ${ }^{143}$

Finally, a reduction in contributions and benefits would dramatically increase tax revenues. The current pension tax regimen is estimated to produce a revenue loss of approximately $\$ 67$ billion a year; that revenue loss would obviously decline as benefits to highly paid employees were reduced. ${ }^{144}$

The case for reduced contributions and benefits is not without problems. While the favorable tax treatment of pension benefits is inconsistent with the Haig-Simons tax ideal, it is consistent with a tax based on consumption. Under a consumption tax, income is measured solely by personal consumption, rather than consumption plus accretion to wealth. ${ }^{145}$ A consumption tax is often thought desirable because it levies the same present value tax burden on immediate or deferred consumption, and because consumption, rather than overall economic resources, is considered to be a more appropriate basis on which to apportion the tax burden.

The treatment of pensions comports with the consumption tax ideal because pension contributions, and the interest earned on those contributions, generally are subject to tax when spent on post-retirement personal consumption. Tax scholars have debated the relative merits of the Haig-Simon and consumption tax ideal for over fifty years without reaching a clear consensus as to which ideal is more desirable. ${ }^{148}$

${ }^{143} \S 61(a)(4)$ (interest included in gross income and is taxed accordingly).

144 See Tax Expenditures: Relationships to Spending Programs and Background Material on Individual Provision, S.Prt.No. 99-159, Senate Committee on the Budget, 99th Cong., 2d Sess. 313 (1986) (estimated 1988 revenue loss $\$ 66.9$ billion). Congressional estimates of revenue loss are probably exaggerated. See Graetz, 135 U.Pa.L.Rev. at 874 (cited in note 6). Nonetheless, the pension savings provisions represent a costly departure from the HaigSimons tax base.

${ }^{145}$ See William D. Andrews, A Consumption-Type or Cash Flow Personal Income Tax, 87 Harv.L.Rev. 1113 (1974).

${ }^{146}$ See Joseph A. Pechman, ed., What Should Be Taxed: Income or Expenditure? (1980); Andrews, 87 Harv.L.Rev. 1113 (cited in note 142); Alvin C. Warren, Jr., Fairness and a Consumption-Type or Cash Flow Personal Income Tax, 88 Harv.L.Rev. 931 (1975). The relative merits of the consumption tax treatment of pension savings is discussed briefly and 
The scholarly debate over the proper tax ideal is reflected in the current tax law. One commentator has characterized the federal tax law as a "hybrid:" certain investments are treated in a manner consistent with a Haig-Simons ideal while other investments are treated in a manner consistent with the consumption tax ideal. ${ }^{147}$ Stock or property appreciation, for example, is a form of accretion to wealth subject to annual tax under the Haig-Simons ideal. However, that form of accretion to wealth is not taxed until the property is sold or exchanged for non-like-kind property; and property is often not sold or exchanged until proceeds are desired for personal consumption. ${ }^{148}$ Thus, while the tax treatment of pensions is inconsistent with the tax treatment of interest-bearing accounts, it often will be consistent with the treatment of stock and property appreciation, and many other investments. ${ }^{148}$

More to the point, even if a reduction in contributions and benefits is thought desirable, the anti-discrimination provisions are an arbitrary means with which to effect such a reduction. As noted above, the effect of the anti-discrimination rules depends critically on the relative interests and bargaining power of highly compensated and rank-and-file employees. In some cases, the anti-discrimination provisions will leave contributions and benefits of highly compensated employees intact and increase contributions and benefits of rank-and-file employees. In such cases, the anti-discrimination provisions will reduce the disparity in tax benefits realized by highly compensated and rank-and-file employees. However, the anti-discrimination provisions will also reduce conformity to the Haig-Simons tax ideal and reduce government tax revenues. Moreover, they will increase the disparity between individuals who save for retirement through pension plans and individuals who must save through currently taxed interest-bearing accounts or

lucidly in Ippolito, Pensions and Economics at 33, 34-38, 62 (cited in note 8). See also Halperin, Tax Policy and Retirement Income at 159-161 (cited in note 27).

${ }^{167}$ Andrews, 87 Harv.L.Rev. at 128-40 (cited in note 142).

148 The non-taxation of property appreciation until such appreciation is "realized" through sale or exchange is often attributed to Eisner v. Macomber, 252 U.S. 189 (1920). See, generally Boris I. Bittker, 1 Federal Taxation of Income, Estates, and Gifts $\S 5.2$ (1981). See also $\$ \S 61,1001,1032$ (rules governing taxation upon sale or non-like-kind exchange). If appreciated stock or property is held until death and transferred through will or devise, the beneficiary may immediately sell the property without recognition of gain. $\S 1014$. In such cases, the appreciation will never be subject to tax.

148 In addition to stock and property appreciation, appreciation of certain financial instruments is not subject to annual tax. For example, the increase in value of annuities is generally not subject to tax until proceeds are distributed. See id. at $\S 72$. See also $\S 101$ (increase in cash value of insurance policy not subject to tax prior to death of insured unless withdrawn; proceeds payable upon death not subject to tax). 
instruments.

In other cases, highly compensated and rank-and-file employees will favor an equally high ratio of pension benefits to salary, and the anti-discrimination provisions will have no effect. In still other cases, employees covered by pension plans will work for employers subject to collective bargaining agreements; such employees will not be subject to the anti-discrimination provisions.

Even in those cases in which the ratio of pension benefits to salary is reduced by the anti-discrimination provisions, the effect of such provisions is almost certain to be sub-optimal. As noted earlier, the anti-discrimination provisions will cause some employers to greatly reduce benefit levels and other employers to reduce benefits levels only slightly.

The distributional, fiscal and conformity-related goals of the anti-discrimination requirements could be better served through other means. Since the adoption of ERISA in 1974, Congress has placed dollar and other limits on the amount of tax-favored contributions and benefits which may accrue to highly compensated employees. ${ }^{150}$ These limits have been extensively debated and significantly amended and strengthened as recently as $1986 .{ }^{151} \mathrm{~A}$ decrease in existing levels of contributions and benefits, if desired, might be effected much more simply through further amendment of these limits.

Poltically, it may be impossible to decrease the limits to the degree desired by opponents of the current tax-favored regimen. However, it may be possible to enact a compromise proposal. A strengthened dollar cap would allow all employees the same amount of tax-favored benefits. In contrast, the anti-discrimination provisions greatly restrict tax-favored benefits to some highly compensated employees and have no effect on other highly compensated employees. If, on the whole, the first dollar of benefits is more valuable to employees than the last dollar of benefits, replacement of the anti-discrimination provisions with a strengthened cap might generate efficiency gains so that the welfare of highly compensated employees could be kept constant even if the cap were set to reduce the aggregate tax benefits. Notwithstanding

${ }^{150}$ Currently, defined benefit plans generally may not provide annual benefits in excess of the lesser of $\$ 90,000$ or $100 \%$ of the employee's average compensation for his highestearning 3 years. Id. at $\S 415(b)$. Defined contribution plans generally may not provide annual contributions in excess of the lesser of $\$ 30,000$ or $25 \%$ of the employee's compensation. § 415(c).

${ }^{151}$ See Tax Reform Act of $1986 \S 1106$ (cited in note 66). 
a net decline in tax benefits, the gain in welfare of employees whose previously low level of benefits would be increased would offset the decline in welfare of employees whose previously high level of benefits would be reduced.

\section{CoNCLUSION}

The anti-discrimination provisions have comprised an important part of the tax law for over four decades. Notwithstanding their enduring nature and significance, however, such provisions seem premised upon surprisingly weak grounds. The anti-discrimination provisions do not, as often thought, provide a straightforward increase in welfare to rank-and-file employees. The provisions are not an efficacious way in which to reduce tax benefits to highly compensated employees; and, despite their title, the antidiscrimination provisions do not seem supported by desirable notions of equality. The provisions force saving for retirement, but here too, alternative measures seem more apt. Seen in the most favorable light, the provisions are justified, if at all, as a temporary, second-best solution to the problems of retirement income and distribution equity.

What, then, should be done? First, the legislative and academic community should examine the impact of the anti-discrimination provisions under more sophisticated, general equilibrium models. A partial equilibrium analysis suggests the anti-discrimination provisions reduce welfare in an arbitrary manner; this result should be tested using more complex models.

Second, debates about governmental policy toward the aged should explicitly acknowledge the role of the anti-discrimination provisions in forcing saving for retirement. Greater attention needs to be paid to scholarship which explores the rationale for such saving. Retirement planning spans a wide array of disciplines; information known to the sociologist is often inaccessible to the tax lawyer or economist. A number of scholars have recently made efforts toward a more interdisciplinary approach to retirement policy: ${ }^{152}$ these efforts should be expanded.

Third, the costs and design of a mandatory universal pension deserve careful study.

Fourth, both the legislative and the academic communities might reexamine the use of other anti-discrimination provisions in

${ }^{152}$ See, for example, Levine, Age Discrimination and Mandatory Retirement (cited in note 105); Martin L. Levine, Elderlaw (1988); Graetz, 135 U.Pa.L.Rev. 851 (cited in note 6). 
the tax law. The receipt of employer-provided and tax-favored medical and dependent care benefits, for example, are conditioned upon compliance with anti-discrimination provisions not discussed in this article. ${ }^{153}$

The formidable empirical and normative issues yet to be resolved argue against immediate action. However, the direction in which the present analysis points toward is clear: the legislature should be prepared to eliminate the anti-discrimination requirements. Limitations on pension-related tax benefits to highly compensated employees should be imposed directly, through a reduction in the amount of pension contributions eligible for favorable treatment. Required retirement saving should also be imposed in a direct fashion, through a mandatory universal pension. Alternatively, retirement income might be supplemented through the social security or general tax-transfer systems. The recommended approaches would be far superior to the arbitrary network of antidiscrimination provisions now in place.

${ }^{163} \S \S 89,105,106,129$. See also $\S \S 117,125,132$ (anti-discrimination provisions applicable to receipt of scholarships, to receipt of fringe benefits such as employee discounts, and to employer plans which allow employees to choose between cash and certain fringe benefits). 